\title{
What Drives Corporate Social Performance? The Role of Espoused National Cultural Values
}

\author{
Namporn Thanetsunthorn* and Rattaphon Wuthisatian ${ }^{\dagger}$ \\ *Pennsylvania State University-Shenango, United States \\ ${ }^{\dagger}$ Southern Oregon University, United States
}

\begin{abstract}
The study examines the impact of national culture on the four important aspects of corporate social responsibility (CSR) - community (COM), employee (EMP), environment (ENV), and governance (GOV). An empirical analysis is based on socially responsible performance of 8,333 corporations from 59 countries across nine different regions around the globe. The findings suggest that Hofstede's four dimensions of national culture - power distance (PDI), individualism (IDV), masculinity (MAS), and uncertainty avoidance (UAI) — have significant impacts on socially responsible corporate performance, either positively or negatively, depending on a given aspect of CSR. Overall, the results explain substantial variations in the effects of different cultural typologies on the corporate social performance and are consistently robust across a variety of statistical methods, including ordinary least squares (OLS) regression, regression with robust standard error, censored normal regression (Tobit), and regression with the inclusion of industry-specific variables. The findings of this study establish useful strategic implications of CSR for business corporations and policymakers, as well as guidance for further academic inquiries.
\end{abstract}

\section{Introduction}

Corporate social responsibility (CSR), a concept that has been around for well over 60 years, has become increasingly significant in 
recent times [Broomhill, 2007]. Not only has CSR become a key topic among businesses and governments [Buhr and Grafström, 2004], but a body of academic literature on CSR has also emerged significant around the CSR topic [Campbell, 2007; Margolis and Walsh, 2003; Walsh et al., 2003].

Nevertheless, little theoretical and empirical attention has been paid to understanding what key factors drive socially responsible corporate behavior or what conditions affect the ability of a corporation to achieve its CSR strategic goals. Indeed, much of the literature on CSR focuses on determining whether corporations ought to engage in CSR [e.g. Friedman, 1970; Jensen, 2002; Levitt, 1958; Porter and Karmer, 2002; Prahalad and Hammond, 2002], and most often the emphasis is on the extent to which engaging in CSR initiatives affects financial performance [see Margolis and Walsh, 2003].

Recently, there has been a growing body of comparative research that seeks to identify the key factors determining socially responsible corporate behavior. However, these efforts give precedence to exploring the formal institutional conditions under which corporations are more or less likely to engage in CSR initiatives. The formal institutional determinants of CSR engagement most often found in the literature involve economic development and public and private regulations, as well as the presence of nongovernmental and other social movement organizations that monitor corporate behavior [Campbell, 2007; Chih et al., 2010; Moon, 2004]. Little attention has been paid to investigating how informal institutional factors, particularly national culture, affect the degree to which corporations engage in CSR and behave in socially responsible ways [Maignan, 2001; Maignan and Ralston, 2002; Margolis and Walsh, 2003].

Traditionally, business corporations are believed to be embedded in the larger society in which they operate, and the characteristics of national culture are the predetermined determinants that shape corporate culture [Allaire and Firsirotu, 1984; Aoki, 1990; Axel, 1995; Basu and Miroshnik, 2003; Hofstede, 1980a, 1994]. The influence of national culture determines the degree to which corporations act in 
socially responsible ways and design their CSR-oriented approach [Habisch et al., 2005; Svensson et al., 2009]. Thus, CSR cannot be understood in isolation from the national cultural context.

From this perspective, several scholars support the idea that the national culture can be a driver that determines the corporation's specific type or preference of CSR activities. For example, Habisch et al.'s (2005) study of 23 national perspectives on the CSR issue provides a comprehensive understanding of CSR development and its progress in each country. The study argues that national culture is the critical predictor that determines the corporation's CSR initiatives. Svensson et al.'s [2009] study of firms in Australia, Canada, and Sweden over two time periods (2001-2002 and 2005-2006) also supports this conceptual framework. The study reveals that ethical structures and processes are different among those corporations and concludes that the way in which corporations outline their approach to business ethics depends on the national culture where they are domiciled. Visser [2008] explores differences of CSR in developing countries as opposed to developed countries. The study mentions cultural tradition as an internal driver of CSR.

Recently, there has been a growing body of literature on the linkages between national culture and CSR. The linkages have been quantified extensively in the existing literature using Hofsetde's four cultural dimensions and corporations' CSR performances derived from a wide variety of reliable data sources. To date, there is still, however, no consensus regarding how each cultural dimension impacts CSR performance. For instance, Ringov and Zollo [2007] empirically examine the effect of national culture on the social and environmental performance of 463 corporations located in 23 North American, European, and Asian cities. The results suggest that power distance and masculinity (MAS) have significant negative effects on the social and environmental performances of the corporations. In their seminal work, Peng et al. [2012] apply the binary regression model on the datasets of the Dow Jones Sustainability index and the Compustat Global Vantage containing 
1,189 corporations and also observe the significant negative impact of power distance and MAS on the CSR engagement. On the other hand, Ho et al. [2012] alternatively report the positive impact of power distance and MAS on corporate social performance among 3,680 companies from 49 developed and developing countries across North America, Europe, and Asia-Pacific.

The effect of individualistic culture on CSR is also reported differently in the existing literature. While Ringov and Zollo [2007] suggest no relationship between individualism (IDV) and CSR, Ho et al. [2012] and Peng et al. [2012] report a significant impact of IDV on CSR; Peng et al. [2012] report a positive effect of IDV on CSR, but Ho et al. [2012] suggest a negative effect. With regard to the effect of uncertainty avoidance culture on CSR, conclusive findings still do not exist. Peng et al.'s [2012] and Ho et al.'s [2012] studies show the positive relationship between uncertainty avoidance and CSR, whereas Ringov and Zollo [2007] report no significant effect of uncertainty avoidance on CSR.

In the work of Thanetsunthorn [2014], causal analyses considering the effect of national culture on different dimensions of CSR community (COM), employee (EMP), environment (ENV) - across different regions of Asia including Eastern Asia, Asia-Pacific, South Asia, and Southeast Asia - are established. The study suggests that a greater home country bias in favor of individualistic culture is significantly and negatively associated with CSR on the aspects of community, employee, and environment. Uncertainty avoidance culture alternatively produces positive impacts on community, employee, and environment dimensions of CSR. Further, higher MAS of a culture has a negative impact on the dimensions of community and employee. The study also shows that there is no relationship between power distance culture and CSR.

An elaboration of the relationship between national culture and CSR is also shown in the comparative study of Thanetsunthorn [2015] based on CSR performance of 3,055 corporations from 28 countries located in Eastern Asia and Europe. The findings suggest that cultures with high level of MAS score lower in CSR on the dimensions of community and employee. Higher power distance and 
IDV of a culture have negative impacts on community, employee, and environment. A high level of CSR on community and environment is associated with a low level of uncertainty avoidance.

Though this topic has progressed substantially, there are still crucial gaps in our knowledge about the effect of national culture on CSR. As discussed above, Ringov and Zollo [2007], Ho et al. [2012], Peng et al. [2012], and Thanetsunthorn [2014, 2015] report interesting evidence indicating the causal relationship between national culture and CSR. The present study differs from these previous studies along several important dimensions. To our knowledge, our study is the first one disclosing this empirical question through the use of global data containing information on 8,333 corporations from 59 countries in nine different regions. We also believe that our study is unique in its examination by distinguishing the effects of national culture on CSR from the effects of geographic region. Moreover, the mentioned authors do not study a wide variety of CSR dimensions, that is, the overall rating of corporate social performance is used as a measure of CSR despite the fact that CSR also encompasses several important aspects of social contributions [Rowley and Berman, 2000; Waddock and Graves, 1997]. At least according to Hancock [2005], CSR is divided into four important aspects: community, employee, environment, and governance. In contrast, our study focuses on these aspects by comparing the effects of national cultures on all the four different dimensions of CSR. In view of the potential implications of our results, we are confident that our results may be beneficial to a consideration of the strategic implications of CSR.

The remainder of this chapter is structured as follows. Section 2 discusses Hofstede's [1980a, 1980b, 2001] four dimensions of national culture - power distance index (PDI), IDV, MAS, and uncertainty avoidance index (UAI) — and the findings of previous studies for establishing our main hypotheses. Section 3 describes the collection of data and its sources with a rationale for selecting the research data. This is followed by the empirical strategy including model specifications testing for the impact of national culture on CSR. Section 4 provides descriptive statistics for the dataset and reports our empirical results. Section 5 presents a summary of noticeable 
facts and main findings of this study. Finally, Section 6 concludes the chapter with implications for business practices and suggestions for future research.

\section{Hypotheses}

\subsection{Hofstede's Four Dimensions of National Culture}

A recent and much heralded empirical model of culture developed by Hofstede [1980a] is valuable for connecting culture to CSR. In essence, Hofstede's work is acknowledged as "one of the most extensive cross-cultural surveys conducted" [Gray, 1988, p. 5], which results in a concise framework of dimensions for differentiating national cultures [Jaeger, 1986]. The definitions of culture and the proposed dimensions are consistent with those identified in a body of social science literature [Gray and Verma, 1998]. Testimony to the recognition of Hofstede's work is a great deal of cross-cultural research in a wide variety of settings and disciplines that employs Hofstede's cultural findings as the theoretical framework. In particular, Hofstede's [1980a, 1980b] model of national culture distinguishing each country's culture from one another can be categorized into four principal dimensions: power distance, IDV versus collectivism, MAS versus femininity, and uncertainty avoidance. These are concisely described by Hofstede as follows:

- Power distance refers to "the extent to which a society accepts the fact that power in institutions and organizations is distributed unequally" [Hofstede, 1980b, p. 45].

- IDV versus collectivism "implies a loosely knit social framework in which people are supposed to take care of themselves and their immediate families only, while collectivism is characterized by a tight social framework in which people distinguish between in-groups and out-groups; they expect their in-group (relatives, clan, organizations) to look after them, and in exchange for that they feel they owe absolute loyalty to it" [Hofstede, 1980b, p. 45].

- MAS versus femininity refers to "the extent to which the dominant values in society are - masculine" that is, assertiveness, the 
acquisition of money and things, and not caring for others, the quality of life, or people" [Hofstede, 1980b, p. 46].

- UAI is "the extent to which a society feels threatened by uncertain and ambiguous situations by providing career stability, establishing more formal rules, not tolerating deviant ideas and behaviors, and believing in absolute truths and the attainment of expertise" [Hofstede, 1980b, p. 46].

\subsection{Power Distance Index (PDI)}

The PDI refers to the degree to which the less powerful members of a society accept and expect that power is distributed unequally. Individuals in high power distance societies tend to accept a hierarchical order and inequality without further justification. On the other hand, those in low power distance societies tend to strive to equalize the distribution of power and are less likely to tolerate such inequality of power.

According to Hofsetde [2001], corporations in high PDI countries tend to have a centralized decision-making structure, where all decisions regarding day-to-day operations and processes are generally made by the top management levels. Employees in high PDI countries are less likely to be involved in the decision-making process. Rather, they expect to be told what to do and follow the executives' obligations and directions. Moreover, corporations within high PDI culture are likely to have less space for diversity and less interest in employee-related CSR activities, such as gender diversity or working conditions [Hofstede, 2001]. Being biased in favor of power distance culture, a more inclusive and stakeholder-oriented approach to management is not favorable to those corporations. To preserve power inequalities existing in those societies, those corporations tend to have a low level of symmetrical communication and information flow [Hofstede, 2001], less diverse board of management, and less disclosure of policies and procedures (high secrecy) [Baydoun and Willett, 1995; Gray, 1988; Perera, 1989; Radebaugh and Gray, 2002].

With regard to the acceptance of the hierarchical order and inequality without further justification, people from a high power distance culture are more likely to view an unethical business 
practice as ethical [Cohen et al., 1996]. As a result, corporations in high PDI countries tend to disregard any negative impact of their operations on the livelihood, health, safety, lifestyle, security, and economic development of the local community. A lack of attention to community welfare also results in being less concerned about the environmental problems caused by their business operations.

Other studies also have found a negative relationship between PDI and corporate social performance of corporations [Peng et al., 2012; Ringov and Zollo, 2007]. Thus, the hypotheses regarding the relationship between PDI and the four important aspects of CSR (community, employee, environment, and governance) are as follows:

H1a: The higher the PDI, the lower the CSR toward community.

H1b: The higher the PDI, the lower the CSR toward employee.

H1c: The higher the PDI, the lower the CSR toward environment.

H1d: The higher the PDI, the lower the CSR toward governance.

\subsection{Individualism (IDV)}

Individualistic culture is defined as a culture or social framework in which individuals primarily focus on their own interests and those of their immediate families [Hofstede, 1980a], rather than group interests. On the other hand, individuals in collectivistic societies are more concerned about the interests and welfares of the group, rather than themselves.

As a bias toward self-interest, corporations in high IDV countries tend to be less sensitive to the welfare of the local community, their employees, and the environment. Akaah's [1990] study finds differences in the ethical behavior between workers in individualistic countries and those in collectivistic countries. The study reveals that workers in corporations in high IDV countries such as Australia, Canada, the United Kingdom, and the United States exhibit less ethically oriented behaviors than do those in collectivistic countries. The primary objectives of corporations in the individualistic societies emphasize profit maximization and cost minimization. As a result, most of the socially responsible corporate activities with respect to community, employee, and environment are perceived as unnecessary 
expenses of a corporation. Subsequently, most CSR projects such as community development, employee development and training programs, and environmental improvement receive far less attention from corporations in high IDV countries. Other studies also find evidence of a negative relationship between IDV and CSR [e.g. Axinn et al., 2004; Ho et al., 2012; Maignan, 2001].

In contrast, corporations in individualistic countries are likely to put shareholders ahead of other stakeholders [Trompenaars and Hampden-Turner, 1997]. Promoting the interest of shareholders and investors is the primary responsibility of a corporation. Corporations in an individualistic culture are more likely to conform to governance principles and practices (i.e. information disclosure, independent board structure, and performance-based compensation). As a result, those corporations exhibit a higher rating of the governancerelated performance than do their counterparts in collectivistic countries.

Another reason supporting socially responsible corporate performance regarding governance is the restricted shareholders and investors' protection law enforcement. Licht et al. [2005] mention that countries with a high score on IDV tend to have a higher quality of shareholders and investors' protection law than collectivistic countries. Consequently, corporations in individualistic countries tend to behave in accordance with the governance guidelines. Although the concept of governance has been highly promoted among collectivistic countries after the 1997 Asian Financial Crisis [OECD, 2000; World Bank, 2001], the corporations in those countries are still reluctant to adopt the governance principles and practices [Buck and Shahrim, 2005] and display a slow pace of countrywide implementation on the governance framework [Ilir and Hans, 2010].

Thus, the hypotheses regarding the relationship between IDV and the four important aspects of CSR are as follows:

H2a: The higher the IDV, the lower the CSR toward community. H2b: The higher the IDV, the lower the CSR toward employee. H2c: The higher the IDV, the lower the CSR toward environment. H2d: The higher the IDV, the higher the CSR toward governance. 


\subsection{Masculinity (MAS)}

Individuals in feminine societies are likely to value relationships, cooperation, caring, modesty, and quality of life [Hofstede, 1980a]. In contrast, in masculine societies, individuals place more value on competitiveness, achievement, assertiveness, power, and material reward for success [Hofstede, 1980a]. Individuals from masculine societies also exhibit less cooperative, sympathetic, and helping behaviors [Steensma et al., 2000; Tice and Baumeister, 2004].

In view of this bias toward their own interests and disregard for the interests of others, one would expect corporations from countries with a high masculine culture to exhibit a lower degree of CSR performance on community, employee, and environment. This expectation is supported by previous studies that demonstrated the negative relationship between MAS and CSR [e.g. Blodgett et al., 2001; Chang and Ding, 1995; Peng et al., 2012; Ringov and Zollo, 2007; Scholtens and Dam, 2007; Yoo and Donthu, 2002].

However, this study expects to see a significant positive relationship between masculine culture and governance-related CSR performance. Because shareholders in masculine-oriented societies stress the importance of performance and achievement, they need to know the values of their holdings in the corporation, and thereby force the corporation to be more transparent and accountable. In the same sense, corporations based in masculine countries are in favor of material advancement, competitiveness, and success. CSR is perceived as an instrument implemented for enhancing the corporation's power connections and reputation [Williams and Zinkin, 2008]. Hence, corporations in countries characterized by high masculine values tend to be more willing to disclose their CSR information, policies, and performance.

Therefore, the hypotheses regarding the relationship between MAS and the four important aspects of CSR are as follows:

H3a: The higher the MAS, the lower the CSR toward community.

H3b: The higher the MAS, the lower the CSR toward employee.

H3c: The higher the MAS, the lower the CSR toward environment.

H3d: The higher the MAS, the higher the CSR toward governance. 


\subsection{Uncertainty Avoidance Index (UAI)}

The UAI refers to the degree to which individuals in a society accept uncertainty and ambiguity. Individuals in societies with a high score on uncertainty avoidance dislike and are uncomfortable with uncertain and ambiguous situations. They prefer rigid codes of conduct, strict laws, and regulations to minimize the uncertainty. On the other hand, individuals in societies with a low score on uncertainty avoidance tend to have flexible attitudes and behaviors. Moreover, they are more likely to engage in risky behavior [Hofstede, 1980a]. Rallapalli et al. [1994] show that high-risk behavior is highly correlated to unethical action.

Data collected from previous studies indicates that there is a positive relationship between high UAI and CSR [Blodgett et al., 2001; Ho et al., 2012; Peng et al., 2012; Ringov and Zollo, 2007]. That is, corporations in high uncertainty avoidance cultures are likely to act in socially responsible ways. Blodgett et al. [2001] argue that individuals from societies high in UAI are likely to be sensitive to the interests of the corporation and stakeholders. Corporations in a high UAI culture tend to avoid having conflict with their stakeholders and act in a manner consistent with the cultural norms, laws, and regulations. Hence, those corporations are more willing to conform and behave in accordance with the shared set of universal ethical standards, as defined in the Universal Declaration of Human Rights, the International Labour Organization's Declaration on Fundamental Principles and Rights at Work, the Rio Declaration on Environment and Development, the United Nations Convention Against Corruption, and the United Nations Global Compact's governance.

Therefore, one would expect corporations from countries with a high UAI culture to exhibit a higher degree of CSR performance on every dimension. The hypotheses regarding the relationship between UAI and the four important aspects of CSR thus are as follows:

H4a: The higher the UAI, the higher the CSR toward community.

H4b: The higher the UAI, the higher the CSR toward employee. 


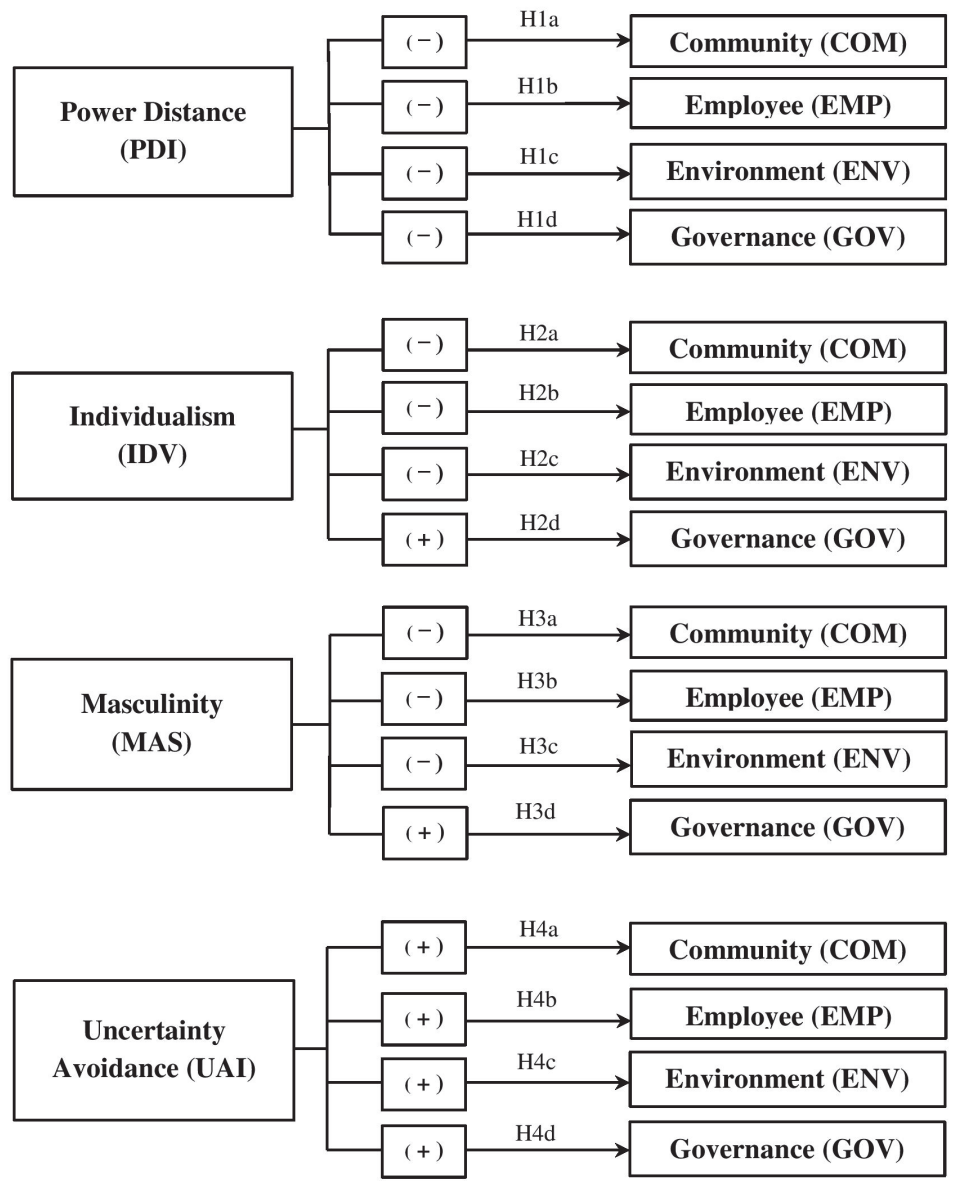

Figure 1. Summary of the hypotheses H1a-H4d.

H4c: The higher the UAI, the higher the CSR toward environment. H4d: The higher the UAI, the higher the CSR toward governance. The summary of the hypotheses is given in Figure 1.

\section{Data and Methodology}

\subsection{Data}

Despite a number of CSR databases and indexes that are widely recognized and used among researchers (e.g. the Kinder, Lydenberg, 
and Domini - KLD, the Fortune Reputation Index, the Canadian Social Investment Database - CSID, and the Global Reporting Initiative (GRI) - GRI), these CSR databases involve several limitations, particularly in the number of observations, countries, and regions, as well as their methodological approaches. The KLD focuses primarily on US companies; the CSID concentrates only on Canadian companies; and even though the Fortune Reputation Index includes representatives of the countries outside of the United States, only 24 industry groups from 13 countries are included in its observation.

With regard to methodological approach, the Fortune Reputation Index uses a survey approach that is a highly perceptual and self-aware measurement of a respondent, and depends mostly on the degree to which a respondent dedicatedly commits to CSR [Aupperle et al., 1985; Graafland et al., 2003, 2004]. Consequently, the assessment of CSR performance is not precise and accurate. Moreover, the Fortune Reputation Index is criticized as relying more on a financial indicator of performance than on a true social performance evaluation [Brown and Perry, 1994; Fryxell and Jia, 1994].

The GRI is widely used for investigating corporate sustainability reporting across cultures around the world. In essence, the GRI's sustainability reporting framework is developed to help corporations report on their environmental, social, and economic performances and increase their accountability. However, the GRI report is widely criticized by academics because it is provided by the company itself. Moreover, many corporations manipulate their environmental, social, and economic performances in order to appear more transparent by overstating their real performance. Supporting evidence is Moneva et al.'s [2006] study, which reviewed the GRI guidelines and its potential impact on corporate reporting and found that "evidence from practice seems to show a different reality. Some organizations that label themselves as GRI reporters do not behave in a responsible way concerning sustainability question, like gas emissions, social equity or human rights" [p. 121]. Furthermore, another limitation of the GRI is that the GRI framework covers what a corporation 
does or does not reveal and report, and its data does not appear as a rating system. Thus, the GRI is not likely to be applicable for identifying corporate sustainability performance.

To avoid the limitations of these other methods, in this study we use the CSRHub database. This database covers more than 8,496 corporations from 104 countries in 10 different regions. Each corporation is assigned to the country in which its corporate headquarters is located. With these large numbers of multinational companies, researchers can learn about and compare the CSR behavior of companies from different countries, regions, or national cultures. Moreover, the CSRHub takes information identifying the social performance of corporations from several sources. This addresses the methodological bias of being more dependent on financial performance rather than social performance of corporations, as well as the limitation of questionnaire-driven methodology.

In essence, the CSRHub uses data from nine sources of the premier socially responsible investment (SRI) - also known as Environment, Social, Governance (ESG) analysis firms, including ASSET4 (Thomson Reuters), Carbon Disclosure Project (CDP), EIRIS, Governance Metrics International (merged with Corporate Library), IW Financial, MSCI (ESG Intangible Value Assessment and ESG Impact Monitor), RepRisk, Trucost, and Vigeo. Furthermore, the information from over 265 nongovernmental organizations (NGOs) such as foundations, associations, union groups, and activist groups, and government databases, publications, and research reports is then augmented with information from other major sources. Overall, more than 41 million pieces of data on CSR performance from over 291 data sources are combined into a consistent set of CSR ratings.

In order to remove bias and inconsistency, the CSRHub's schema is developed according to the GRI's G3.1 guideline. The CSRHub's schema involves the four key categories, where each consists of three subcategories. In essence, the CSRHub schema is tied to the corporation's CSR performance and based upon a 0 to 100 rating scale. A high score represents a positive rating $(100=$ extremely positive rating). The CSR performance scores of a corporation obtained from different data sources are then compared and analyzed 
with regard to variations between data sources. Each source is weighted based on the credibility and quality of the sources, and then all the data from different sources are combined to generate base ratings at the subcategory level. The rating for each of the 12 subcategories is then aggregated to the four key categories. If there is no conclusive agreement between data sources or corporations, the corporations' ratings are excluded from the CSRHub database.

Regarding the large number of observations and data sources as well as the proprietary methods to process and adjust data, the CSRHub database is representative of the general state of knowledge about the social performance of the corporations and of the bestavailable information that fits the objectives of this study.

To test the proposed hypotheses, the CSR ratings for four categories of CSR activities - community, employee, environment, and governance - of 8,496 corporations from 104 countries in 10 regions are collected from the CSRHub. Then, these corporations are supplemented with measures of national cultural values obtained from Hofstede's dimensions of national culture [Hofstede, 2001; Hofstede et al., 2010] including PDI, IDV, MAS, and UAI. To identify the pure effect of culture on CSR, the study also controls for the effects of other variables that might influence the CSR performance of a corporation. Previous studies suggest that CSR performance is influenced mainly by three factors within a specific country: level of economic development, standard of living, and law and regulation. Thus, the following variables are used as proxies in the study to control the potential effects of these three factors:

- Gross domestic product (GDP) is one of the primary indicators used to measure the health of a country's economy. It represents the sum of gross values of all goods and services produced over a specific time period. Data is in current US dollars. The data is collected from the World Bank's official website.

- Human development index (HDI) refers to the country's "potential" human development as well as human well-being. The HDI index consists of life expectancy, educational attainment, and income indicators. It reflects a long and healthy life, the average 
year of schooling and expected years of schooling, and standard of living. A higher HDI score indicates higher human development. The data is gathered from the United Nations Development Program.

- Law and Order refers to a country's strength and impartiality of the legal system as well as popular observance of the law. A score of six points equates to a very low risk and a score of 0 points to a very high risk. The data is obtained from the International Country Risk Guide database provided by the PRS Group. ${ }^{1}$

The literature also suggests that regional differences can lead to an unsystematic variation of CSR practices [Donleavy et al., 2008; Ho et al., 2012; Tan and Chow, 2009; Thanetsunthorn, 2014, 2015]. Moreover, CSR performance and practices depend on a specific type of industry with certain characteristics, stakeholders, and contexts in which the corporations operate [Cruz and Boehe, 2010; Decker, 2004]. Therefore, both industry and regional clusters are used to create the industry-specific and the region-specific dummy variables for each corporation. ${ }^{2}$

The total number of observations is 8,333 corporations from 59 countries in nine different regions: Africa (South Africa, Egypt, Ghana, Morocco, and Nigeria), Asia-Pacific (Australia, New Zealand, and Philippines), Eastern Asia (China, Hong Kong, Japan, South Korea, and Taiwan), Europe (Austria, Belgium, Croatia, Denmark, Finland, France, Germany, Greece, Hungary, Ireland, Italy, Latvia,

\footnotetext{
${ }^{1}$ The ICRG database is a reliable source that has furnished an international clientele with ratings affecting political, economic, and financial risks, and that has been acclaimed in several reliable publications (e.g. The Economist, and The Wall Street Journal), and particularly the published paper by Robert J. Barro, the Nobel Prize winner from Harvard University.

${ }^{2}$ Industry-specific dummy variables: Agriculture \& Mining, Construction \& Engineering, Consumer Goods, Distribution, Durable Goods, Education \& Government, Finance \& Real Estate, Food, Beverages, \& Tobacco, Healthcare, Media, Multi-Industry, Retail, Services, Sports \& Leisure, Technology, Transportation, Travel, and Utilities \& Refining. Region-specific dummy variables: Africa, AsiaPacific, Eastern Asia, Europe, Middle East, North America, South America, South Asia, and Southeast Asia.
} 
Luxembourg, Netherlands, Norway, Poland, Portugal, Russia, Serbia, Slovenia, Spain, Sweden, Switzerland, and United Kingdom), Middle East (Israel, Kuwait, Saudi Arabia, Turkey, and United Arab Emirates), North America (Canada, Mexico, and United States), South America (Argentina, Brazil, Chile, Colombia, Ecuador, Peru, Uruguay, and Venezuela), South Asia (India and Pakistan), and Southeast Asia (Indonesia, Malaysia, Singapore, and Thailand).

\subsection{Empirical Strategy}

In our empirical analysis, the following functional relationship will be empirically examined:

$$
\mathrm{CSR}_{i, j}=f\left(\text { Culture }_{i, k}, X\right), \quad \text { where } i=\text { corporation and } j \neq k
$$

which can be linearized for regression estimates as follows:

$$
\mathrm{CSR}_{i, j}=\beta_{0}+\beta_{1} \text { Culture }_{i, k}+\beta_{x} X+\varepsilon_{i}
$$

The subscript $j$ denotes each dimension of CSR for corporation $i$, including COM, EMP, ENV, and GOV, and the subscript $k$ denotes each cultural dimension of the country where corporation $i$ is located, including PDI, IDV, MAS, and UAI. The variable $X$ is a vector set of control variables including GDP, HDI, law and order, and industry-specific variables. Then, to control for the effects of geographic regions, we develop dichotomous variables $R_{m}$, namely region-specific dummy variables, to designate the region of a country where corporation $i$ is located. Subsequently, the reduced forms of the regression function can be written as

$$
\begin{aligned}
\mathrm{CSR}_{i, j}= & \beta_{0}+\beta_{1} \mathrm{PDI}_{i}+\beta_{2} \mathrm{IDV}_{i}+\beta_{3} \mathrm{MAS}_{i}+\beta_{4} \mathrm{UAI}_{i} \\
& +\sum_{m=1}^{8} \gamma_{m} R_{m}+\beta_{x} X+\varepsilon_{i}
\end{aligned}
$$

Condition (3) contains eight region-specific dummy variables, including Africa, Asia-Pacific, Europe, Middle East, North America, South 
America, South Asia, and Southeast Asia. ${ }^{3}$ Note that the sum of the region dummy variable equals to unity $\sum_{m=1}^{8} R_{m}=1$. Therefore, the regression functions for each dimension of the CSR performance for the total nine regions can be written as follows:

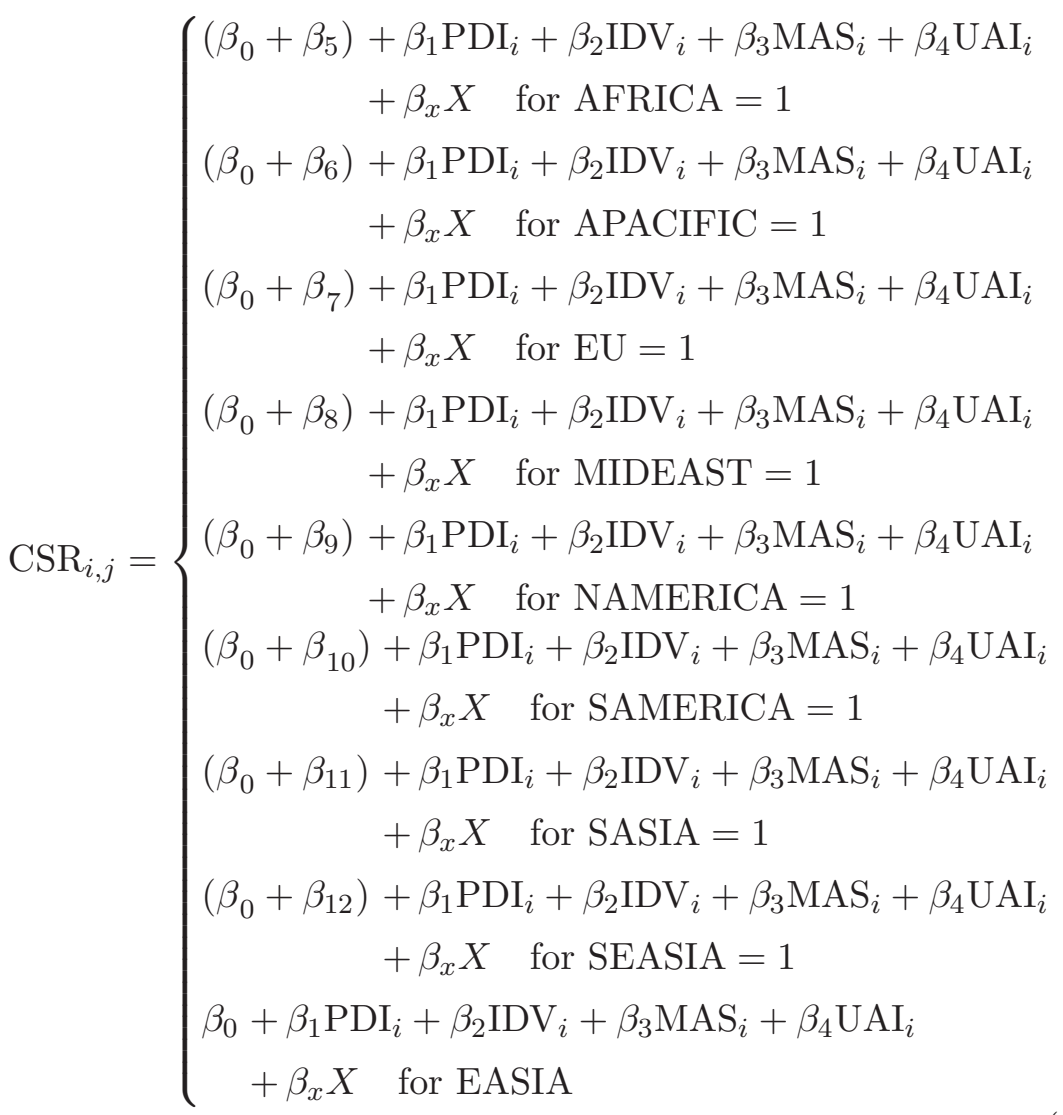

To ensure the robustness of our findings, regression with robust standard errors, censored normal (Tobit) and regression with the

\footnotetext{
${ }^{3}$ The dummy variable of Eastern Asia (EASIA) was excluded from condition (3) because it would have created a model in which exact collinearity exists. Statistically, CSR performance of the Eastern Asian corporations is treated as a constant term in all of the estimated models.
} 
industry-specific dummy variables are also performed after obtaining the results from the basic OLS regression. ${ }^{4}$

\section{Results}

\subsection{Descriptive Statistics}

Table 1 reports the descriptive statistics of the average CSR ratings on COM, EMP, ENV, and GOV of 8,333 corporations as of 2013, as well as a summary of Hofstede's four cultural dimensions: PDI, IDV, MAS, and UAI.

As shown in the table, ENV receives, on average, a higher rating (55.04 points) across the board, while GOV receives the lowest average rating (51.67 points). The average rating of COM (52.04 points) is slightly lower than that of EMP (53.43 points) but still considerably higher than that of GOV. The standard deviation across all four dimensions varies between 10 and 12 points. Further support for the differences among the average ratings of the four aspects of CSR can be gained from Figure 2.

Table 1. Descriptive statistics.

\begin{tabular}{lcccrr}
\hline Variable & $N$ & Mean & S.D. & Min & Max \\
\hline CSR dimensions & & & & & \\
COM & 7,796 & 52.04 & 10.94 & 14 & 91 \\
EMP & 7,624 & 53.43 & 10.81 & 6 & 88 \\
ENV & 7,719 & 55.04 & 10.59 & 8 & 94 \\
GOV & 8,080 & 51.67 & 11.17 & 7 & 93 \\
National cultures & & & & & \\
PDI & 8,333 & 47.52 & 15.74 & 11 & 104 \\
IDV & 8,333 & 69.61 & 26.68 & 8 & 91 \\
MAS & 8,333 & 60.22 & 15.33 & 5 & 95 \\
UAI & 8,333 & 53.43 & 18.96 & 8 & 112 \\
\hline
\end{tabular}

\footnotetext{
${ }^{4}$ The regression model is constructed based on evidence provided by previous studies. It is also important to note that endogeneity due to omitted variables may violate the assumption of the classical linear regression model that the error term is uncorrelated with the explanatory variables. The problem may reduce regression precision and cause misleading results.
} 


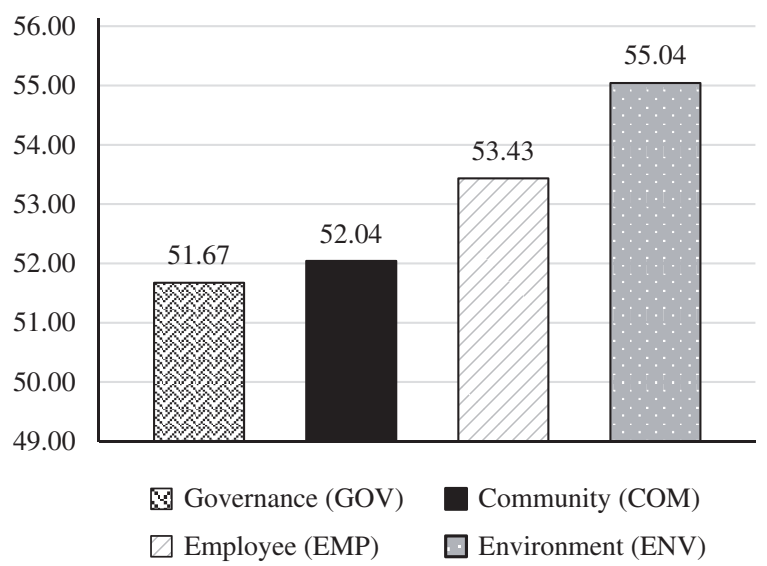

Figure 2. The average CSR ratings on community, employee, environment, and governance.

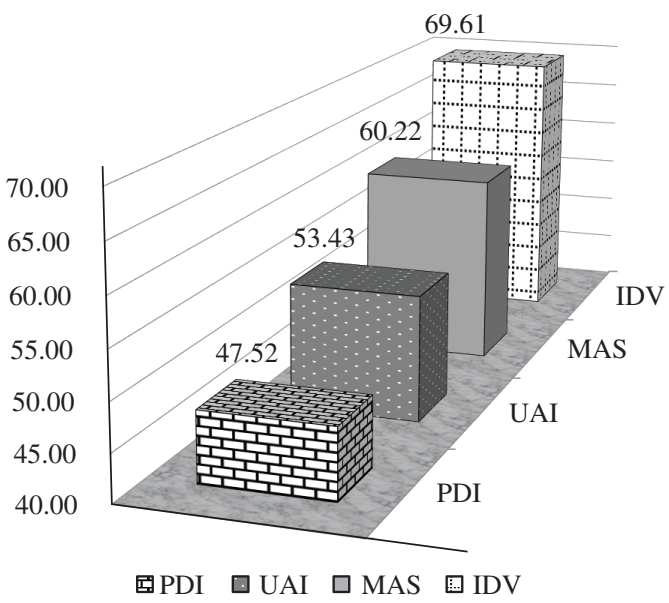

Figure 3. The average ratings on PDI, IDV, MAS, and UAI.

Referring to Hofstede's four dimensions of national culture, the average ratings of PDI, IDV, MAS, and UAI are 47.52 points, 69.61 points, 60.22 points, and 53.43 points, respectively. Figure 3 graphically shows differences in the average ratings among these four cultural dimensions. 


\subsection{Paired Samples t-test}

In order to assess the level of statistical difference, this study uses a paired samples $t$-test analysis. The results in Table 2 show that ENV receives the highest rating: at $1 \%$ level of significance, it is higher than COM, with $t$-stat. $=29.87$; higher than GOV, with $t$-stat. $=20.31$; and higher than EMP, with $t$-stat. $=11.41$. The table also shows that GOV, on average, receives the lowest rating: at $1 \%$ level of significance, it is less than ENV, with $t$-stat. $=-20.31$; less than EMP, with $t$-stat. $=-15.24$; and less than COM, with $t$-stat. $=-1.68$ at $10 \%$ level of significance. The paired samples $t$-test results also show that the rating of EMP is significantly higher than that of COM, with $t$-stat. $=13.91$, at $1 \%$ level of significance.

Table 3 shows the results of the paired samples $t$-test analyses of Hofstede's four dimensions of national culture. The score of PDI, on average, is significantly lower across the board: at $1 \%$ level of significance, it is lower than IDV, with $t$-stat. $=-50.13$; lower than MAS, with $t$-stat. $=-52.60$; and lower than UAI, with $t$-stat. $=$ -24.79 . The table also shows that IDV has a higher score across the board: at the $1 \%$ level of significance, it is higher than PDI, with

Table 2. Paired samples $t$-test among four aspects of CSR.

\begin{tabular}{lc}
\hline Pair sample & $t$-Statistics \\
\hline COM versus EMP & $-13.91^{* * *}$ \\
COM versus ENV & $-29.87^{* * *}$ \\
COM versus GOV & $1.68^{*}$ \\
EMP versus COM & $13.91^{* * *}$ \\
EMP versus ENV & $-11.41^{* * *}$ \\
EMP versus GOV & $15.24^{* * *}$ \\
ENV versus COM & $29.87^{* * *}$ \\
ENV versus EMP & $11.41^{* * *}$ \\
ENV versus GOV & $20.31^{* * *}$ \\
GOV versus COM & $-1.68^{*}$ \\
GOV versus EMP & $-15.24^{* * *}$ \\
GOV versus ENV & $-20.31^{* * *}$ \\
\hline Notes: ${ }^{*} p<0.10 ;$ & $* *$ \\
${ }^{* * *} p<0.01$. &
\end{tabular}


Table 3. Paired samples $t$-test among Hofstede's four dimensions of national culture.

\begin{tabular}{lr}
\hline Paired sample & $t$-Statistics \\
\hline PDI versus IDV & $-50.13^{* * *}$ \\
PDI versus MAS & $-52.60^{* * *}$ \\
PDI versus UAI & $-24.79^{* * *}$ \\
IDV versus PDI & $50.13^{* * *}$ \\
IDV versus MAS & $29.32^{* * *}$ \\
IDV versus UAI & $38.03^{* * *}$ \\
MAS versus PDI & $52.60^{* * *}$ \\
MAS versus IDV & $-29.32^{* * *}$ \\
MAS versus UAI & $27.45^{* * *}$ \\
UAI versus PDI & $24.79^{* * *}$ \\
UAI versus IDV & $-38.03^{* * *}$ \\
UAI versus MAS & $-27.45^{* * *}$ \\
\hline$N^{* *}:^{*} p<0.10 ;$ & $* * *<0.05 ;$ \\
${ }^{* * *} p<0.01$. & $<$
\end{tabular}

$t$-stat. $=50.13$; higher than MAS, with $t$-stat. $=29.32 ;$ and higher than the UAI, with $t$-stat. $=38.03$. Additionally, the results show that the average score of MAS is higher than that of UAI, with $t$-stat. $=27.45$ at $1 \%$ level of significance.

\subsection{Pearson Product-Moment Correlation Coefficient}

Table 4 shows the correlations among the four dimensional aspects of CSR with Hofstede's four dimensions of national culture. The significant positive correlations suggest a high internal consistency in which one dimension has a positive effect on an increase of the other dimensions. In particular, an increase in COM is strongly correlated with the increase in EMP, ENV, and GOV: the correlation coefficients of $+0.57,+0.53$, and +0.25 are statistically significant at less than the $1 \%$ level, respectively. A strong positive relationship also exists between EMP and ENV and GOV; the correlation coefficients of +0.34 and +0.36 , respectively, are statistically significant at less than the $1 \%$ level. Furthermore, the correlation coefficient of +0.15 at less than the $1 \%$ level of significance indicates that the positive 
Table 4. Pearson product-moment correlation coefficient.

\begin{tabular}{lcccccccc}
\hline & COM & EMP & ENV & GOV & PDI & IDV & MAS & UAI \\
\hline COM & 1.00 & & & & & & & \\
EMP & $0.57^{* * *}$ & 1.00 & & & & & & \\
ENV & $0.53^{* * *}$ & $0.34^{* * *}$ & 1.00 & & & & & \\
GOV & $0.25^{* * *}$ & $0.36^{* * *}$ & $0.15^{* * *}$ & 1.00 & & & & \\
PDI & $-0.02^{* *}$ & $-0.03^{* *}$ & $-0.05^{* * *}$ & $-0.07^{* * *}$ & 1.00 & & & \\
IDV & $0.04^{* * *}$ & $0.04^{* * *}$ & $0.05^{* * *}$ & $0.05^{* * *}$ & $-0.79^{* * *}$ & 1.00 & & \\
MAS & $-0.09^{* * *}$ & $-0.15^{* * *}$ & 0.02 & $-0.17^{* * *}$ & -0.01 & $0.11^{* * *}$ & 1.00 & \\
UAI & 0.003 & $-0.03^{* *}$ & $0.03^{* * *}$ & $-0.14^{* * *}$ & $0.22^{* * *}$ & $-0.43^{* * *}$ & $0.15^{* * *}$ & 1.00 \\
\hline
\end{tabular}

Notes: ${ }^{*} p<0.10 ;{ }^{* *} p<0.05 ;{ }^{* * *} p<0.01$.

relationship between ENV and GOV is also strong. We note that only two dimensions, EMP and GOV, are significantly correlated with all of Hofstede's four cultural dimensions. For the CSR performance on community, three of Hofstede's cultural dimensions - PDI, IDV, and MAS - are significantly correlated with COM. ENV is significantly correlated with all of Hofstede's cultural dimensions except MAS. The direction and significance of associations among these relationships differ among variables.

\subsection{OLS Regression: Effect of National Culture on CSR}

The estimates for the effects of national culture and socially responsible corporate performance related to community, employee, environment, and governance in the OLS regression, Regression with Robust Standard Errors, Censored Normal (Tobit), and OLS regression with industry-specific dummy variables models are given in Tables 5-8.

Table 5 shows the significant negative effects of PDI, IDV, and MAS on COM of corporations $(p<0.01)$ across all specifications. In contrast, UAI shows a significant positive effect on COM $(p<$ 0.01) across all specifications. The findings provide strong support for H1a, H2a, H3a, and H4a. Corporations in high PDI countries, where people accept inequality, and are more likely to tolerate such inequality of power, are significantly and negatively associated with 
Table 5. The effect of national culture on community-related CSR performance.

\begin{tabular}{|c|c|c|c|c|}
\hline \multirow[b]{2}{*}{ Variable } & \multicolumn{4}{|c|}{$\mathrm{COM}$} \\
\hline & OLS & $\begin{array}{c}\text { Robust } \\
\text { standard } \\
\text { errors }\end{array}$ & $\begin{array}{c}\text { Censored } \\
\text { normal } \\
\text { (Tobit) }\end{array}$ & $\begin{array}{l}\text { OLS (with } \\
\text { industry } \\
\text { dummies) }\end{array}$ \\
\hline PDI & $\begin{array}{l}-0.07^{* * *} \\
(0.02)\end{array}$ & $\begin{array}{l}-0.07^{* * *} \\
(0.02)\end{array}$ & $\begin{array}{l}-0.07^{* * *} \\
(0.02)\end{array}$ & $\begin{array}{l}-0.07^{* * *} \\
(0.02)\end{array}$ \\
\hline IDV & $\begin{array}{l}-0.12^{* * *} \\
(0.02)\end{array}$ & $\begin{array}{l}-0.12^{* * *} \\
(0.02)\end{array}$ & $\begin{array}{l}-0.12^{* * *} \\
(0.02)\end{array}$ & $\begin{array}{l}-0.12^{* * *} \\
(0.02)\end{array}$ \\
\hline MAS & $\begin{array}{l}-0.07^{* * *} \\
(0.01)\end{array}$ & $\begin{array}{l}-0.07^{* * *} \\
(0.01)\end{array}$ & $\begin{array}{l}-0.07^{* * *} \\
(0.01)\end{array}$ & $\begin{array}{l}-0.07^{* * *} \\
(0.01)\end{array}$ \\
\hline UAI & $\begin{array}{l}0.03^{* * *} \\
(0.01)\end{array}$ & $\begin{array}{l}0.03^{* * *} \\
(0.01)\end{array}$ & $\begin{array}{l}0.03^{* * *} \\
(0.01)\end{array}$ & $\begin{array}{l}0.03^{* * *} \\
(0.01)\end{array}$ \\
\hline AFRICA & $\begin{array}{l}7.35^{* * *} \\
(1.33)\end{array}$ & $\begin{array}{l}7.35^{* * *} \\
(1.30)\end{array}$ & $\begin{array}{l}7.35^{* * *} \\
(1.33)\end{array}$ & $\begin{array}{l}7.07^{* * *} \\
(1.32)\end{array}$ \\
\hline APACIFIC & $\begin{array}{l}5.80^{* * *} \\
(1.04)\end{array}$ & $\begin{array}{l}5.80^{* * *} \\
(1.00)\end{array}$ & $\begin{array}{l}5.80^{* * *} \\
(1.04)\end{array}$ & $\begin{array}{l}5.83^{* * *} \\
(1.04)\end{array}$ \\
\hline $\mathrm{EU}$ & $\begin{array}{l}6.44^{* * *} \\
(0.78)\end{array}$ & $\begin{array}{l}6.44^{* * *} \\
(0.83)\end{array}$ & $\begin{array}{l}6.44^{* * *} \\
(0.78)\end{array}$ & $\begin{array}{l}6.13^{* * *} \\
(0.78)\end{array}$ \\
\hline MIDEAST & $\begin{array}{c}1.25 \\
(1.29)\end{array}$ & $\begin{array}{l}1.25 \\
(1.31)\end{array}$ & $\begin{array}{c}1.25 \\
(1.29)\end{array}$ & $\begin{array}{c}1.35 \\
(1.29)\end{array}$ \\
\hline NAMERICA & $\begin{array}{l}2.70^{* * *} \\
(0.84)\end{array}$ & $\begin{array}{l}2.70^{* * *} \\
(0.87)\end{array}$ & $\begin{array}{l}2.70^{* * *} \\
(0.84)\end{array}$ & $\begin{array}{l}2.93^{* * *} \\
(0.84)\end{array}$ \\
\hline SAMERICA & $\begin{array}{l}7.41^{* * *} \\
(0.95)\end{array}$ & $\begin{array}{l}7.41^{* * *} \\
(1.07)\end{array}$ & $\begin{array}{l}7.40^{* * *} \\
(0.95)\end{array}$ & $\begin{array}{l}7.35^{* * *} \\
(0.95)\end{array}$ \\
\hline SASIA & $\begin{array}{l}10.68^{* * *} \\
(1.26)\end{array}$ & $\begin{array}{l}10.68^{* * *} \\
(1.29)\end{array}$ & $\begin{array}{l}10.68^{* * *} \\
(1.26)\end{array}$ & $\begin{array}{l}10.63^{* * *} \\
(1.25)\end{array}$ \\
\hline SEASIA & $\begin{array}{l}3.01^{* * *} \\
(0.93)\end{array}$ & $\begin{array}{l}3.01^{* * *} \\
(0.89)\end{array}$ & $\begin{array}{l}3.01^{* * * *} \\
(0.93)\end{array}$ & $\begin{array}{l}2.93^{* * *} \\
(0.92)\end{array}$ \\
\hline GDP & $\begin{array}{c}5.96 \times 10^{-13 * * *} \\
\left(5.46 \times 10^{-14}\right)\end{array}$ & $\begin{array}{c}5.96 \times 10^{-13 * * *} \\
\left(5.09 \times 10^{-14}\right)\end{array}$ & $\begin{array}{c}5.97 \times 10^{-13 * * *} \\
\left(5.47 \times 10^{-14}\right)\end{array}$ & $\begin{array}{c}5.57 \times 10^{-13 * * *} \\
\left(5.55 \times 10^{-14}\right)\end{array}$ \\
\hline HDI & $\begin{array}{c}5.26^{* *} \\
(2.39)\end{array}$ & $\begin{array}{c}5.26^{* *} \\
(2.23)\end{array}$ & $\begin{array}{c}5.26^{* *} \\
(2.39)\end{array}$ & $\begin{array}{r}4.36^{*} \\
(2.38)\end{array}$ \\
\hline Law Order & $\begin{array}{c}0.005 \\
(0.17)\end{array}$ & $\begin{array}{c}0.005 \\
(0.18)\end{array}$ & $\begin{array}{c}0.01 \\
(0.17)\end{array}$ & $\begin{array}{c}-0.03 \\
(0.17)\end{array}$ \\
\hline $\begin{array}{l}\text { Industry } \\
\text { Dummies }\end{array}$ & NO & NO & NO & YES \\
\hline _cons & $\begin{array}{l}54.32^{* * *} \\
(2.80)\end{array}$ & $\begin{array}{l}54.32^{* * *} \\
(2.61)\end{array}$ & $\begin{array}{l}54.32^{* * *} \\
(2.80)\end{array}$ & $\begin{array}{l}54.94^{* * *} \\
(2.89)\end{array}$ \\
\hline$N$ & 7446 & 7446 & 7446 & 7443 \\
\hline$R$-squared & 0.04 & 0.04 & $\mathrm{~N} / \mathrm{A}$ & 0.06 \\
\hline
\end{tabular}

Notes: Robust standard errors in parentheses; ${ }^{*} p<0.10 ;{ }^{* *} p<0.05 ;{ }^{* * *} p<0.01$. Tobit Regression: 1 left-censored observation at community-related CSR performance score $\leq 15$ and 23 right-censored observations at community-related CSR performance score $\geq 85$. 
COM. Likewise, corporations based in countries characterized by IDV and MAS cultures — where individuals in society primarily focus on their own interests rather than the group interests and are biased in favor of MAS values such as competitiveness, achievement, assertiveness, power, and material reward for success — tend to exhibit lower levels of COM. On the other hand, corporations based in a more UAI culture exhibit higher levels of COM.

The relationship between national culture and EMP is presented in Table 6. The results show significant negative effects of IDV and MAS on EMP $(p<0.01)$ across all specifications. In contrast, UAI has a significant positive effect on $\operatorname{EMP}(p<0.01)$ across all four regression models. For the significance and direction of associations between PDI and EMP, the findings show a negative direction, as hypothesized. However, the association is at the $10 \%$ level of significance in OLS regression and Censored Normal (Tobit), but does not show up after correcting and minimizing variance in the OLS estimation (see Table 6). After controlling for the industryspecific effect, the significance of association between PDI and EMP increases from $10 \%$ to $5 \%$ level. The increase implies that the effect of industry-specific dummy variables dominates the effect of PDI on EMP. Overall, the findings in Table 6 provide strong support for H1b, $\mathrm{H} 2 \mathrm{~b}, \mathrm{H} 3 \mathrm{~b}$, and H4b. Corporations based in countries with higher levels of PDI, IDV, and MAS exhibit lower levels of EMP, whereas corporations with higher levels of EMP are significantly associated with cultures that tend to prefer a rigid code of conduct, strict laws, and regulations to minimize uncertainty (UAI).

The results in Table 7 show significant negative effects of PDI and IDV on ENV $(p<0.01)$ across all specifications. In contrast, UAI has a significant positive effect on ENV $(p<0.01)$ across all specifications. Thus, the findings provide strong support for H1c, H2c, and H4c. Although a negative effect of MAS on ENV does exist as predicted, the association is not significant at any conventional level. Therefore, the findings strongly contradict H3c, which states that corporations based in countries that are biased in favor of masculine values tend to exhibit lower levels of ENV. The interpretation is that corporations based in countries with high 
Table 6. The effect of national culture on employee-related CSR performance.

\begin{tabular}{|c|c|c|c|c|}
\hline \multirow[b]{2}{*}{ Variable } & \multicolumn{4}{|c|}{ EMP } \\
\hline & OLS & $\begin{array}{c}\text { Robust } \\
\text { standard } \\
\text { errors }\end{array}$ & $\begin{array}{c}\text { Censored } \\
\text { normal } \\
\text { (Tobit) }\end{array}$ & $\begin{array}{c}\text { OLS (with } \\
\text { industry } \\
\text { dummies) }\end{array}$ \\
\hline PDI & $\begin{array}{r}-0.03^{*} \\
(0.02)\end{array}$ & $\begin{array}{c}-0.03 \\
(0.02)\end{array}$ & $\begin{array}{r}-0.03^{*} \\
(0.02)\end{array}$ & $\begin{array}{c}-0.04^{* *} \\
(0.02)\end{array}$ \\
\hline IDV & $\begin{array}{l}-0.09^{* * *} \\
(0.02)\end{array}$ & $\begin{array}{l}-0.09^{* * *} \\
(0.02)\end{array}$ & $\begin{array}{l}-0.09^{* * *} \\
(0.02)\end{array}$ & $\begin{array}{l}-0.09^{* * *} \\
(0.02)\end{array}$ \\
\hline MAS & $\begin{array}{l}-0.06^{* * *} \\
(0.01)\end{array}$ & $\begin{array}{l}-0.06^{* * *} \\
(0.01)\end{array}$ & $\begin{array}{l}-0.07^{* * *} \\
(0.01)\end{array}$ & $\begin{array}{l}-0.06^{* * *} \\
(0.01)\end{array}$ \\
\hline UAI & $\begin{array}{l}0.02^{* * *} \\
(0.01)\end{array}$ & $\begin{array}{l}0.02 * * \\
(0.01)\end{array}$ & $\begin{array}{l}0.02^{* * *} \\
(0.01)\end{array}$ & $\begin{array}{l}0.02^{* * *} \\
(0.01)\end{array}$ \\
\hline AFRICA & $\begin{array}{l}9.55^{* * *} \\
(1.35)\end{array}$ & $\begin{array}{l}9.55^{* * *} \\
(1.49)\end{array}$ & $\begin{array}{l}9.59^{* * *} \\
(1.35)\end{array}$ & $\begin{array}{l}9.65^{* * *} \\
(1.34)\end{array}$ \\
\hline APACIFIC & $\begin{array}{l}9.16^{* * *} \\
(1.04)\end{array}$ & $\begin{array}{l}9.16^{* * *} \\
(1.14)\end{array}$ & $\begin{array}{l}9.25^{* * *} \\
(1.05)\end{array}$ & $\begin{array}{l}8.97^{* * *} \\
(1.04)\end{array}$ \\
\hline $\mathrm{EU}$ & $\begin{array}{l}9.12^{* * *} \\
(0.79)\end{array}$ & $\begin{array}{l}9.12^{* * *} \\
(0.92)\end{array}$ & $\begin{array}{l}9.23^{* * *} \\
(0.80)\end{array}$ & $\begin{array}{l}8.96^{* * *} \\
(0.79)\end{array}$ \\
\hline MIDEAST & $\begin{array}{c}-0.13 \\
(1.26)\end{array}$ & $\begin{array}{c}-0.13 \\
(1.59)\end{array}$ & $\begin{array}{c}-0.21 \\
(1.27)\end{array}$ & $\begin{array}{c}-0.08 \\
(1.26)\end{array}$ \\
\hline NAMERICA & $\begin{array}{l}6.76^{* * *} \\
(0.85)\end{array}$ & $\begin{array}{l}6.76^{* * *} \\
(0.96)\end{array}$ & $\begin{array}{l}6.83^{* * *} \\
(0.85)\end{array}$ & $\begin{array}{l}6.57^{\text {*** }} \\
(0.85)\end{array}$ \\
\hline SAMERICA & $\begin{array}{l}12.12^{* * *} \\
(0.97)\end{array}$ & $\begin{array}{l}12.12^{* * *} \\
(1.18)\end{array}$ & $\begin{array}{l}12.17^{* * *} \\
(0.97)\end{array}$ & $\begin{array}{l}11.52^{* * *} \\
(0.97)\end{array}$ \\
\hline SASIA & $\begin{array}{l}13.90^{* * *} \\
(1.33)\end{array}$ & $\begin{array}{l}13.90^{* * *} \\
(1.43)\end{array}$ & $\begin{array}{l}14.06^{* * *} \\
(1.33)\end{array}$ & $\begin{array}{l}13.83^{* * *} \\
(1.32)\end{array}$ \\
\hline SEASIA & $\begin{array}{l}2.77^{* * *} \\
(0.96)\end{array}$ & $\begin{array}{l}2.77^{* * *} \\
(0.91)\end{array}$ & $\begin{array}{l}2.81^{* * *} \\
(0.96)\end{array}$ & $\begin{array}{l}2.74^{* * *} \\
(0.96)\end{array}$ \\
\hline GDP & $\begin{array}{c}1.93 \times 10^{-13 * * *} \\
\left(5.37 \times 10^{-14}\right)\end{array}$ & $\begin{array}{c}1.93 \times 10^{-13 * * *} \\
\left(5.15 \times 10^{-14}\right)\end{array}$ & $\begin{array}{c}1.96 \times 10^{-13 * * *} \\
\left(5.39 \times 10^{-14}\right)\end{array}$ & $\begin{array}{c}2.11 \times 10^{-13 * * *} \\
\left(5.46 \times 10^{-14}\right)\end{array}$ \\
\hline HDI & $\begin{array}{c}5.39^{* *} \\
(2.42)\end{array}$ & $\begin{array}{c}5.39^{* *} \\
(2.41)\end{array}$ & $\begin{array}{c}5.42^{* *} \\
(2.42)\end{array}$ & $\begin{array}{l}5.14^{* *} \\
(2.41)\end{array}$ \\
\hline Law Order & $\begin{array}{c}-0.06 \\
(0.18)\end{array}$ & $\begin{array}{c}-0.06 \\
(0.21)\end{array}$ & $\begin{array}{c}-0.06 \\
(0.18)\end{array}$ & $\begin{array}{c}-0.07 \\
(0.18)\end{array}$ \\
\hline $\begin{array}{l}\text { Industry } \\
\text { Dummies }\end{array}$ & NO & $\mathrm{NO}$ & NO & YES \\
\hline _cons & $\begin{array}{l}51.72^{* * *} \\
(2.85)\end{array}$ & $\begin{array}{l}51.72^{* * *} \\
(2.93)\end{array}$ & $\begin{array}{l}51.73^{* * *} \\
(2.86)\end{array}$ & $\begin{array}{l}51.47^{* * *} \\
(2.94)\end{array}$ \\
\hline$N$ & 7301 & 7301 & 7301 & 7298 \\
\hline$R$-squared & 0.07 & 0.07 & $\mathrm{~N} / \mathrm{A}$ & 0.09 \\
\hline
\end{tabular}

Notes: Robust standard errors in parentheses; ${ }^{*} p<0.10 ;{ }^{* *} p<0.05 ;{ }^{* * *} p<0.01$. Tobit Regression: 15 left-censored observations at employee-related CSR performance score $\leq 15$ and 26 right-censored observations at employee-related CSR performance score $\geq 85$. 
Table 7. The effect of national culture on environment-related CSR performance.

\begin{tabular}{|c|c|c|c|c|}
\hline \multirow[b]{2}{*}{ Variable } & \multicolumn{4}{|c|}{ ENV } \\
\hline & OLS & $\begin{array}{l}\text { Robust } \\
\text { standard } \\
\text { errors }\end{array}$ & $\begin{array}{c}\text { Censored } \\
\text { normal } \\
\text { (Tobit) }\end{array}$ & $\begin{array}{l}\text { OLS (with } \\
\text { industry } \\
\text { dummies) }\end{array}$ \\
\hline PDI & $\begin{array}{l}-0.05^{* * *} \\
(0.02)\end{array}$ & $\begin{array}{c}-0.05^{* * *} \\
(0.02)\end{array}$ & $\begin{array}{c}-0.05^{* * *} \\
(0.02)\end{array}$ & $\begin{array}{c}-0.05^{* * *} \\
(0.02)\end{array}$ \\
\hline IDV & $\begin{array}{l}-0.07^{* * *} \\
(0.02)\end{array}$ & $\begin{array}{l}-0.07^{* * *} \\
(0.02)\end{array}$ & $\begin{array}{l}-0.07^{* * *} \\
(0.02)\end{array}$ & $\begin{array}{l}-0.07^{* * *} \\
(0.02)\end{array}$ \\
\hline MAS & $\begin{array}{c}-0.01 \\
(0.01)\end{array}$ & $\begin{array}{c}-0.01 \\
(0.01)\end{array}$ & $\begin{array}{c}-0.01 \\
(0.01)\end{array}$ & $\begin{array}{r}-0.002 \\
(0.01)\end{array}$ \\
\hline UAI & $\begin{array}{l}0.03^{* * *} \\
(0.01)\end{array}$ & $\begin{array}{l}0.03^{* * *} \\
(0.01)\end{array}$ & $\begin{array}{l}0.03^{* * *} \\
(0.01)\end{array}$ & $\begin{array}{l}0.03^{* * *} \\
(0.01)\end{array}$ \\
\hline AFRICA & $\begin{array}{l}4.44^{* * *} \\
(1.27)\end{array}$ & $\begin{array}{l}4.44^{* * *} \\
(1.19)\end{array}$ & $\begin{array}{l}4.43^{* * *} \\
(1.27)\end{array}$ & $\begin{array}{l}4.54^{* * *} \\
(1.25)\end{array}$ \\
\hline APACIFIC & $\begin{array}{l}0.47 \\
(0.99)\end{array}$ & $\begin{array}{c}0.47 \\
(0.89)\end{array}$ & $\begin{array}{c}0.46 \\
(0.98)\end{array}$ & $\begin{array}{c}0.94 \\
(0.97)\end{array}$ \\
\hline $\mathrm{EU}$ & $\begin{array}{l}3.11^{* * *} \\
(0.74)\end{array}$ & $\begin{array}{l}3.11^{* * *} \\
(0.71)\end{array}$ & $\begin{array}{l}3.11^{* * *} \\
(0.74)\end{array}$ & $\begin{array}{l}3.18^{* * *} \\
(0.73)\end{array}$ \\
\hline MIDEAST & $\begin{array}{c}1.25 \\
(1.26)\end{array}$ & $\begin{array}{c}1.25 \\
(1.28)\end{array}$ & $\begin{array}{c}1.29 \\
(1.26)\end{array}$ & $\begin{array}{c}1.99 \\
(1.24)\end{array}$ \\
\hline NAMERICA & $\begin{array}{c}0.69 \\
(0.80)\end{array}$ & $\begin{array}{c}0.69 \\
(0.77)\end{array}$ & $\begin{array}{c}0.69 \\
(0.80)\end{array}$ & $\begin{array}{l}1.32^{*} \\
(0.79)\end{array}$ \\
\hline SAMERICA & $\begin{array}{l}4.29^{* * *} \\
(0.88)\end{array}$ & $\begin{array}{l}4.29^{* * *} \\
(0.82)\end{array}$ & $\begin{array}{l}4.29^{* * *} \\
(0.88)\end{array}$ & $\begin{array}{l}4.39^{* * *} \\
(0.86)\end{array}$ \\
\hline SASIA & $\begin{array}{l}7.10^{* * *} \\
(1.21)\end{array}$ & $\begin{array}{l}7.10^{* * *} \\
(1.27)\end{array}$ & $\begin{array}{l}7.09^{* * *} \\
(1.21)\end{array}$ & $\begin{array}{l}6.79^{* * *} \\
(1.20)\end{array}$ \\
\hline SEASIA & $\begin{array}{c}0.16 \\
(0.90)\end{array}$ & $\begin{array}{c}0.16 \\
(0.90)\end{array}$ & $\begin{array}{c}0.15 \\
(0.90)\end{array}$ & $\begin{array}{c}0.41 \\
(0.89)\end{array}$ \\
\hline GDP & $\begin{array}{c}4.43 \times 10^{-13 * * *} \\
\left(5.24 \times 10^{-14}\right)\end{array}$ & $\begin{array}{c}4.43 \times 10^{-13 * * *} \\
\left(4.48 \times 10^{-14}\right)\end{array}$ & $\begin{array}{c}4.42 \times 10^{-13 * * *} \\
\left(5.23 \times 10^{-14}\right)\end{array}$ & $\begin{array}{l}3.86 \times 10^{-13 * * *} \\
\left(5.26 \times 10^{-14}\right)\end{array}$ \\
\hline HDI & $\begin{array}{l}7.17^{* * *} \\
(2.23)\end{array}$ & $\begin{array}{l}7.17^{* * *} \\
(1.96)\end{array}$ & $\begin{array}{l}7.16^{* * *} \\
(2.23)\end{array}$ & $\begin{array}{l}5.92^{* * *} \\
(2.20)\end{array}$ \\
\hline Law order & $\begin{array}{c}0.17 \\
(0.16)\end{array}$ & $\begin{array}{c}0.17 \\
(0.16)\end{array}$ & $\begin{array}{c}0.17 \\
(0.16)\end{array}$ & $\begin{array}{c}0.10 \\
(0.16)\end{array}$ \\
\hline $\begin{array}{l}\text { Industry } \\
\text { dummies }\end{array}$ & NO & NO & NO & YES \\
\hline _cons & $\begin{array}{l}50.15^{* * *} \\
(2.63)\end{array}$ & $\begin{array}{l}50.15^{* * *} \\
(2.40)\end{array}$ & $\begin{array}{l}50.14^{* * *} \\
(2.63)\end{array}$ & $\begin{array}{l}55.25^{* * *} \\
(2.71)\end{array}$ \\
\hline$N$ & 7358 & 7358 & 7358 & 7355 \\
\hline$R$-squared & 0.03 & 0.03 & $\mathrm{~N} / \mathrm{A}$ & 0.07 \\
\hline
\end{tabular}

Notes: Robust standard errors in parentheses; ${ }^{*} p<0.10 ;{ }^{* *} p<0.05 ;{ }^{* * *} p<0.01$. Tobit Regression: 1 left-censored observation at environment-related CSR performance score $\leq 15$ and 26 right-censored observations at environment-related CSR performance score $\geq 85$. 
Table 8. The effect of national culture on governance-related CSR performance.

\begin{tabular}{|c|c|c|c|c|}
\hline \multirow[b]{2}{*}{ Variable } & \multicolumn{4}{|c|}{ GOV } \\
\hline & OLS & $\begin{array}{l}\text { Robust } \\
\text { standard } \\
\text { errors }\end{array}$ & $\begin{array}{c}\text { Censored } \\
\text { normal } \\
\text { (Tobit) }\end{array}$ & $\begin{array}{l}\text { OLS (with } \\
\text { industry } \\
\text { dummies) }\end{array}$ \\
\hline PDI & $\begin{array}{c}-0.01 \\
(0.02)\end{array}$ & $\begin{array}{c}-0.01 \\
(0.01)\end{array}$ & $\begin{array}{c}-0.01 \\
(0.02)\end{array}$ & $\begin{array}{r}-0.01 \\
(0.02)\end{array}$ \\
\hline IDV & $\begin{array}{c}0.02 \\
(0.02)\end{array}$ & $\begin{array}{c}0.02 \\
(0.01)\end{array}$ & $\begin{array}{c}0.02 \\
(0.02)\end{array}$ & $\begin{array}{c}0.03 \\
(0.02)\end{array}$ \\
\hline MAS & $\begin{array}{l}-0.05^{* * *} \\
(0.01)\end{array}$ & $\begin{array}{l}-0.05^{* * *} \\
(0.01)\end{array}$ & $\begin{array}{l}-0.05^{* * *} \\
(0.01)\end{array}$ & $\begin{array}{l}-0.05^{* * *} \\
(0.01)\end{array}$ \\
\hline UAI & $\begin{array}{l}-0.08^{* * *} \\
(0.01)\end{array}$ & $\begin{array}{l}-0.08^{* * *} \\
(0.01)\end{array}$ & $\begin{array}{l}-0.08^{* * *} \\
(0.01)\end{array}$ & $\begin{array}{l}-0.08^{* * *} \\
(0.01)\end{array}$ \\
\hline [5pt] AFRICA & $\begin{array}{l}5.54^{* * *} \\
(1.29)\end{array}$ & $\begin{array}{l}5.54^{* * *} \\
(1.19)\end{array}$ & $\begin{array}{l}5.53^{* * *} \\
(1.28)\end{array}$ & $\begin{array}{l}5.78^{* * *} \\
(1.28)\end{array}$ \\
\hline APACIFIC & $\begin{array}{l}3.40^{* * *} \\
(1.00)\end{array}$ & $\begin{array}{l}3.40^{* * *} \\
(0.80)\end{array}$ & $\begin{array}{l}3.40^{* * *} \\
(0.99)\end{array}$ & $\begin{array}{l}3.50^{* * *} \\
(0.99)\end{array}$ \\
\hline EU & $\begin{array}{l}4.51^{* * *} \\
(0.74)\end{array}$ & $\begin{array}{l}4.51^{* * *} \\
(0.65)\end{array}$ & $\begin{array}{l}4.52^{* * *} \\
(0.74)\end{array}$ & $\begin{array}{l}4.44^{* * *} \\
(0.74)\end{array}$ \\
\hline MIDEAST & $\begin{array}{c}1.82 \\
(1.25)\end{array}$ & $\begin{array}{c}1.82 \\
(1.36)\end{array}$ & $\begin{array}{c}1.81 \\
(1.25)\end{array}$ & $\begin{array}{c}2.09^{*} \\
(1.25)\end{array}$ \\
\hline NAMERICA & $\begin{array}{l}3.81^{* * *} \\
(0.80)\end{array}$ & $\begin{array}{l}3.81^{* * *} \\
(0.72)\end{array}$ & $\begin{array}{l}3.81^{* * *} \\
(0.80)\end{array}$ & $\begin{array}{l}3.89^{* * *} \\
(0.80)\end{array}$ \\
\hline SAMERICA & $\begin{array}{l}5.10^{* * *} \\
(0.88)\end{array}$ & $\begin{array}{l}5.10^{* * *} \\
(0.82)\end{array}$ & $\begin{array}{l}5.10^{* * *} \\
(0.88)\end{array}$ & $\begin{array}{l}4.80^{* * *} \\
(0.88)\end{array}$ \\
\hline SASIA & $\begin{array}{l}3.65^{\text {*** }} \\
(1.23)\end{array}$ & $\begin{array}{l}3.65^{* * *} \\
(1.18)\end{array}$ & $\begin{array}{l}3.67^{* * *} \\
(1.22)\end{array}$ & $\begin{array}{l}3.74^{* * *} \\
(1.22)\end{array}$ \\
\hline SEASIA & $\begin{array}{c}-0.90 \\
(0.92)\end{array}$ & $\begin{array}{c}-0.90 \\
(0.84)\end{array}$ & $\begin{array}{c}-0.90 \\
(0.92)\end{array}$ & $\begin{array}{c}-0.77 \\
(0.92)\end{array}$ \\
\hline GDP & $\begin{array}{c}-5.36 \times 10^{-13 * * *} \\
\left(5.22 \times 10^{-14}\right)\end{array}$ & $\begin{array}{c}-5.36 \times 10^{-13 * * *} \\
\quad\left(4.17 \times 10^{-14}\right)\end{array}$ & $\begin{array}{c}-5.36 \times 10^{-13 * * *} \\
\left(5.22 \times 10^{-14}\right)\end{array}$ & $\begin{array}{c}-5.37 \times 10^{-13 * * *} \\
\quad\left(5.30 \times 10^{-14}\right)\end{array}$ \\
\hline HDI & $\begin{array}{l}-2.98 \\
(2.24)\end{array}$ & $\begin{array}{l}-2.98 \\
(1.89)\end{array}$ & $\begin{array}{l}-3.00 \\
(2.24)\end{array}$ & $\begin{array}{c}-3.01 \\
(2.23)\end{array}$ \\
\hline Law Order & $\begin{array}{l}0.42^{* * *} \\
(0.17)\end{array}$ & $\begin{array}{l}0.42^{* * *} \\
(0.16)\end{array}$ & $\begin{array}{l}0.42^{* * *} \\
(0.17)\end{array}$ & $\begin{array}{l}0.41^{* * *} \\
(0.17)\end{array}$ \\
\hline $\begin{array}{l}\text { Industry } \\
\text { Dummies }\end{array}$ & NO & NO & NO & YES \\
\hline _cons & $\begin{array}{l}59.31^{* * *} \\
(2.65)\end{array}$ & $\begin{array}{l}59.31^{* * *} \\
(2.25)\end{array}$ & $\begin{array}{l}59.30^{* * *} \\
(2.65)\end{array}$ & $\begin{array}{l}59.69^{* * *} \\
(2.75)\end{array}$ \\
\hline$N$ & 7719 & 7719 & 7719 & 7716 \\
\hline$R$-squared & 0.13 & 0.13 & $\mathrm{~N} / \mathrm{A}$ & 0.14 \\
\hline
\end{tabular}

Notes: Robust standard errors in parentheses; ${ }^{*} p<0.10 ;{ }^{* *} p<0.05 ;{ }^{* * *} p<0.01$. Tobit Regression: 8 left-censored observations at governance-related CSR performance score $\leq 15$ and 11 right-censored observations at governance-related CSR performance score $\geq 85$. 
scores on PDI and IDV emphasize less concern about the impact of business on the environment, whereas corporations based in countries with high UAI are more concerned about the impact of business on the environment because of the strict enforcement on environment laws and regulations.

The results presented in Table 8 demonstrate the significant negative effects of MAS and UAI on GOV $(p<0.01)$ across all specifications. The interpretation is that corporations based in countries characterized by MAS culture, where individuals in society are biased in favor of competitiveness, achievement, assertiveness, power, and material reward for success, tend to exhibit lower levels of GOV. Likewise, corporations based in a more UAI-oriented culture, where individuals prefer rigid codes of conduct, strict laws, and regulations to minimize the uncertainty, are likely to exhibit lower levels of GOV. Although there is a negative direction of association between PDI and GOV, as predicted, the association is not significant at any conventional level. IDV has a positive association on GOV, but no significant effect is borne out at any conventional level. Hence, H1d, H2d, H3d, and H4d are not confirmed by our findings.

\section{Discussion and Conclusion}

\subsection{Noticeable Facts}

\subsubsection{Noticeable fact 1}

The rating of environment-related CSR performance on average is higher across the board, whereas the aspect of governance-related CSR performance exhibits the lowest rating.

As shown in the results of the paired samples $t$-test, a degree of corporate sensitivity to social issues is varied. On average, addressing environmental problems is ranked as a primary concern for business corporations, whereas governance receives far less attention from businesses. Moreover, business corporations are more committed to serving their employees than serving external stakeholders (community). A pyramid of the CSR orientations is illustrated in Figure 4. 


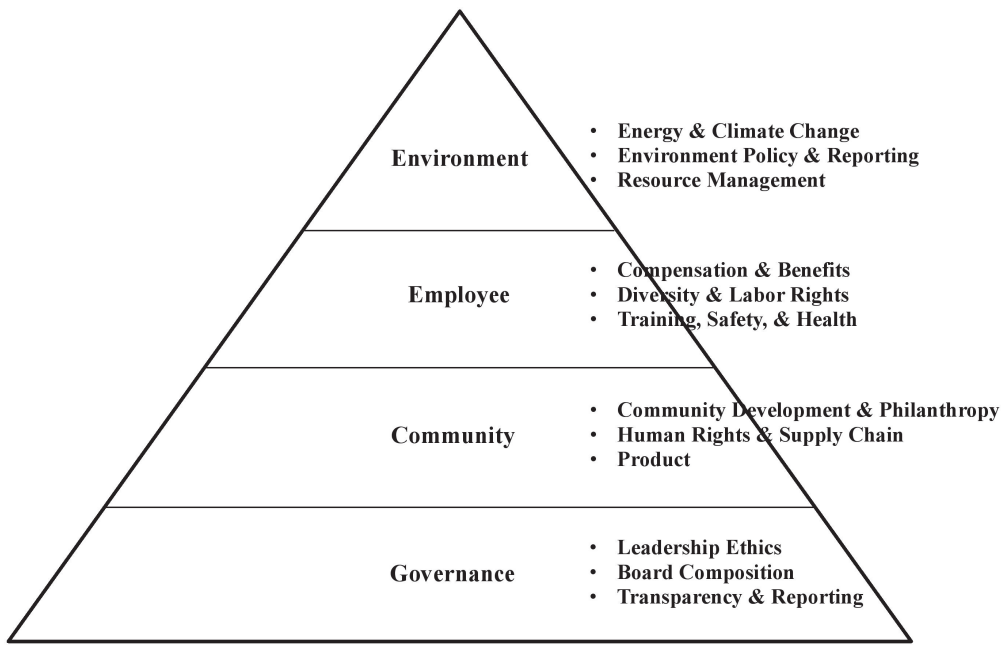

Figure 4. Pyramid of the CSR orientations.

These findings are supported by recent evidence of Pfeffer [2010] arguing that the contemporary milieu of business social contributions places heavy emphasis on the environment, with less attention given to other spheres of CSR. One explanation is that the consequences of social contributions on the environment are more visible, concrete, and easier to measure [Bebbington and Dillard, 2009; Davidson, 2009]. Most important, it is related, in part, to corporate financial performance [Peiyuan, 2005]. On the other hand, other aspects of corporate social contribution are difficult to measure, report, and interpret in the same way [Brown et al., 2009].

Another explanation is related to changes in laws and an increase in public concern over environmental problems. Pfeffer [2010] argued that strict laws and regulations have been passed in many countries to ensure that the business corporations abide by the local environmental laws and international standards, and engage in voluntary environmental reporting and disclosure. Hence, in response to these trends, corporations are forced to improve and disclose their environmental performance.

With regard to the lowest rating of governance-related CSR performance, the explanation is strongly connected to the uncertain 
outcomes of good governance engagement. That is, good governance creates not only a good outcome but also a bad outcome associated with the risks of losing profitability. Such risks involve the loss of trust in the management level among shareholders and investors and the uncertainty in financial stability.

The evolution of the concept and definition of CSR is another critical reason for the lowest rating of governance-related CSR performance. In retrospect, the impressive history associated with the evolution of the concept and definition of CSR beginning in the 1950s [Carroll, 1999] merely adheres to a role of business in addressing social problems and contributing to the broad society. The following are some examples of CSR at that time:

"Social responsibility means the commitment of a business or Business, in general, to an active role in the solution of broad social problems, such as racial discrimination, pollution, transportation, or urban decay." [Eilbert and Parket, 1973, p. 7]

"Employment of minority groups, reduction in pollution, greater participation in programs to improve the community, improved medical care, improved industrial health and safety - these and other programs designed to improve the quality of life are covered by the broad umbrella of social responsibility." [Backman, 1975, pp. 2-3]

As seen above, the evolution of the concept and definition of CSR emphasizes the obligations of a business toward the community, employee, and environment, whereas the conceptual framework of good governance is not incorporated into the CSR concept and definition. Corporations turn a blind eye to good governance when they think through the CSR framework.

\subsubsection{Noticeable fact 2}

Strong positive relationships exist among the four dimensional aspects of CSR.

Based on the findings from the Pearson product-moment correlation coefficient, strong positive correlations exist among the four aspects of CSR. These correlations suggest a high internal consistency in which one aspect has a positive effect on an increase of the other aspects, and vice versa. 
The findings of links between governance-related CSR performance and the other three aspects of socially responsible corporate performance are in agreement with several other studies [e.g. Elkington, 2006; Grosser and Moon, 2005; Hancock, 2005; Perrini et al., 2006; Rosam and Peddle, 2004; Thanetsunthorn and Wuthisatian, 2016]. Hence, the findings of this study further support the role of a good governance system as the basic building block for leveraging sustainable CSR. In particular, this study further argues that good corporate governance and CSR are not distinguishable pieces of corporate strategy; rather, they are closely interrelated and mutually supportive.

Moreover, given the evidence about the positive relationship between corporate social and financial performances suggested by a majority of the previous studies [e.g. Allouche and Laroche, 2005; Cochran and Wood, 1984; Griffin and Mahon, 1997; Margolis and Walsh, 2003; Orlitzy et al., 2003; Posnikoff, 1997; Waddock and Graves, 1997; Wu, 2006], a good governance system within a corporation appears to be a critical factor that indirectly fosters the positive relationship between corporate social and financial performances. And if this assumption is accurate, then promoting the adoption of good corporate governance standards and practices along with partaking in CSR initiatives can contribute to achieving substantial and sustainable improvements in corporate financial performance.

\subsection{Main Findings}

\subsubsection{Main finding 1}

The higher the PDI, the lower the CSR performance related to community, employee, and environment.

The findings from the OLS regression (see Tables 5-8) show that a greater home country tolerance of power distance is significantly and negatively associated with the socially responsible corporate performance related to community, employee, and environment. On the other hand, power distance culture has no relationship with the governance-related CSR performance.

In general, individuals from countries with high PDI scores tend to accept hierarchical order and inequality as natural. On the 
contrary, those from countries with low PDI scores are less likely to tolerate such inequality and tend to strive for an equal distribution of power. Being tolerant of inequality, people in high power distance societies are more likely to accept questionable business practices as ethical [Cohen et al., 1996]. In the absence of questions about business practices that mitigate unethical behavior, corporations will have interests and incentives that may cause them to behave in socially irresponsible ways. In other words, in the absence of these public inquiries, corporations will be more likely to behave irresponsibly than they would if such inquiries were present.

In addition, corporations in a high power distance culture tend to have a centralized organizational structure in which decision-making rights and responsibilities are ultimately retained by the top CEOs and management levels. Employees are likely to be less involved in decision-making processes, and they expect to be told and follow what they have been told by their boss.

This study does not find clear implications of power distance culture for the rating of governance-related CSR performance. The reason might be the fact that Hofstede's power distance dimension of national culture relates to power distribution among groups of people that differ in their social classes and hierarchies within a society, whereas the rating of governance-related CSR performance places more emphasis on the dynamics among multiple stakeholders both inside and outside a corporation. If outside stakeholders enjoy more power, they will be empowered to use governance principles and standards as mechanisms to monitor board management and stakeholders within the organization. On the other hand, if corporation's internal stakeholders are more powerful, they will be able to resist the use of governance mechanisms.

\subsubsection{Main finding 2}

The higher the IDV, the lower the CSR performance related to community, employee, and environment.

On the basis of the findings from the OLS regression (see Tables 5-8), a greater home country bias in favor of individualistic culture is significantly and negatively associated with the socially responsible corporate performance related to community, employee, 
and environment. Although this study finds a positive direction of association between IDV and governance-related CSR performance as predicted, the significance of this positive association does not exist at any conventional level.

In general, individuals in a high individualistic culture are more likely to focus on their own interests and place their personal selfinterests ahead of the welfares and interests of others. On the contrary, those in collectivistic societies are more sensitive to the interests and welfares of others rather than themselves. Being biased in favor of their own self-interests, people and corporations in high individualistic countries tend to behave in socially irresponsible ways and participate less in CSR activities [Akaah, 1990].

Valuing self-interest and personal advancement is also transplanted onto the objectives and goals of corporations in that culture. Corporations in an individualistic culture place higher priority on profit maximization and cost reduction than on social contribution. Hence, most CSR projects incurring organizational expenses such as community development, employee development and training programs, and sustainable environment programs receive far less attention from corporations in individualistic countries.

The findings of this study are consistent with the works of Axinn et al. [2004], Maignan [2001], Ho et al. [2012], and Thanetsunthorn [2014, 2015], which collectively suggest the negative association between IDV and socially responsible corporate performance.

\subsubsection{Main finding 3}

The higher the MAS, the lower the CSR performance related to community, employee, and governance.

The findings from the OLS regression (see Tables 5-8) indicate that a greater home country bias in favor of masculine culture is significantly and negatively associated with the socially responsible corporate performance related to community, employee, and governance.

In masculine societies, individuals focus more on competitiveness, achievement, assertiveness, power, and material reward for success [Hofstede, 1980a]. Thus, they are likely to exhibit less 
ethically oriented behaviors such as caring, helpfulness, and socially supporting other people [Chang and Ding, 1995; Vitell and Festervand, 1987]. Being biased toward their own interests and disregarding the interests of others, corporations from countries with a high score on MAS exhibit a lower degree of socially responsible corporate performance related to community and employee. The findings of this study are consistent with a majority of the previous studies that collectively demonstrated the negative effect of MAS on corporate social performance and ethical behavior [e.g. Blodgett et al., 2001; Chang and Ding 1995; Peng et al., 2012; Ringov and Zollo, 2007; Scholtens and Dam, 2007; Yoo and Donthu, 2002].

With regard to the impact of masculine culture on environmentrelated CSR performance, a negative direction of association does exist as hypothesized. However, no statistical significance was found in this study. Hence, the findings of this study are consistent with the works of Once and Almagtome [2014] and Thanetsunthorn [2014], which indicate the absence of the associated relationship between MAS and environment-related CSR performance.

Contrary to expectation, this study found a significant negative effect of MAS on governance-related CSR performance. The likely reason is the concern for losing corporate financial gain [Blodgett et al., 2001; Chang and Ding 1995; Peng et al., 2012; Ringov and Zollo, 2007; Scholtens and Dam, 2007; Vitell and Festervand, 1987; Yoo and Donthu, 2002]. Investment in activities that uphold corporate governance standards and mechanisms will be perceived as excessive costs and unnecessary expenses. Consequently, corporations in masculine societies tend to exhibit lower levels in their governance-related CSR performance.

\subsubsection{Main finding 4}

The higher the UAI, the higher the CSR performance related to community, employee, and environment, the lower the CSR performance related to governance.

As shown in the findings from the OLS regression (see Tables 5-8), a greater home country bias in favor of uncertainty avoidance culture is significantly and positively associated with 
socially responsible corporate performance related to community, employee, and environment. The findings of this study are strongly consistent with the work of Thanetsunthorn [2014], which indicates the positive relationships between uncertainty avoidance culture and CSR performance on community, employee, and environment. However, uncertainty avoidance culture has a significant negative effect on governance-related CSR performance.

Individuals in high uncertainty avoidance societies are more likely to be concerned about the interests of others [Blodgett et al., 2001] and prefer rigid codes of conduct, strict laws, and regulations to minimize the uncertainty and ambiguity. In contrast, individuals with a low UAI score tend to be more flexible in their attitudes and behaviors. Furthermore, they are willing to take risks [Hofstede, 1980a] and tend to behave in socially irresponsible ways [Rallapalli et al., 1994]. To avoid risky situations that can damage the company's image and reputation, corporations in high uncertainty avoidance societies are willing to comply with laws, regulations, and a shared set of universal ethical standards. Therefore, corporations from countries with a high uncertainty avoidance culture are more likely to behave in socially responsible ways toward community, employee, and environment.

As noted, however, the findings of this study reveal a significant negative direction between uncertainty avoidance culture and governance-related CSR performance that contradicts the main hypothesis. According to Gray [1988], a high UAI culture is consistent with a preference for secrecy to preserve security. The more the need for job security, the less the amount of information disclosure and transparency. Hence, a management board in a high UAI culture is likely to disclose less information in order to minimize the possibility of risk of losing credibility with shareholders.

In summary, PDI and IDV have significant negative effects on the socially responsible corporate performance related to COM, EMP, and ENV. In addition, MAS has significant negative effects on COM, EMP, and GOV. In contrast, the results also show that UAI has significant positive effects on COM, EMP, and ENV, but it has a significant negative effect on performance related to 
Table 9. Summary of the dynamic relationships of Hofstede's four dimensions of national culture and four aspects of corporate social performance.

\begin{tabular}{llccc}
\hline $\begin{array}{l}\text { Hofstede's } \\
\text { cultural } \\
\text { dimensions }\end{array}$ & \multicolumn{4}{l}{ Socially responsible corporate performance } \\
\cline { 2 - 5 } & COM & EMP & ENV & GOV \\
\hline PDI & $(-)^{* * *}$ & $(-)^{*}$ & $(-)^{* * *}$ & $(-)$ \\
IDV & $(-)^{* * *}$ & $(-)^{* * *}$ & $(-)^{* * *}$ & $(+)$ \\
MAS & $(-)^{* * *}$ & $(-)^{* * *}$ & $(-)$ & $(-)^{* * *}$ \\
UAI & $(+)^{* * *}$ & $(+)^{* * *}$ & $(+)^{* * *}$ & $(-)^{* * *}$ \\
\hline Notes: ${ }^{*} p<0.10 ;{ }^{* *} p<0.05 ;{ }^{* * *} p<0.01$.
\end{tabular}

GOV. The dynamic relationships of Hofstede's four dimensions of national culture and four aspects of socially responsible corporate performance are summarized in Table 9 .

\section{Implications and Future Research}

In light of our research findings, the strategic implications of CSR for business and policymakers are offered. Key to the findings is the acknowledgment of the role of national culture in nurturing and undermining socially responsible corporate performance. In an internationalization process, it is important for multinational corporations to evaluate their potential demand for customizing their CSR strategies and activities to fit with the cultural environment of the host country in which they operate. For policymakers who deal with social policies and CSR issues, our empirical results can be used as a framework for assessing foreign investors' preferences regarding CSR engagement and activities. Lastly, our findings provide important insights into the formulation of enabling policy for investment so as to reap the full benefits of foreign direct investment for sustainable development.

A number of interesting extensions to this study are possible. First, to better understand the effect of national culture on CSR, there is potential to explore the impact of each cultural dimension espoused in a particular country/region on socially responsible 
performance of corporations embedded in that country/region. Second, valuable insight can be gained by using a time-series analysis to capture the dynamic relationship of national culture and socially responsible corporate performance through time. Third, due to the fact that our study is limited to the examination of the effects of Hofstede's four cultural dimensions, power distance, IDV, MAS, and uncertainty avoidance, it would be of great interest to investigate the impacts of other national cultural dimensions, for instance, longterm orientation versus short-term orientation and indulgence versus restraint. ${ }^{5}$ According to McWilliams et al. [2006], cultural differences lead to different expectations and different returns to CSR activities. A fourth avenue for future research is to apply the two-stage least squares (2SLS) regression to estimate how national culture affects firms' CSR activities and how those affected CSR activities could subsequently influence firms' financial returns.

\section{References}

Akaah, I. P. (1990). Attitudes of marketing professionals toward ethics in marketing research: A cross-national comparison, Journal of Business Ethics, $9(1)$, pp. $45-53$.

Allaire, Y. and Firsirotu, M. E. (1984). Theories of organizational culture, Organization Studies, 5(3), pp. 193-266.

Allouche, J. and Laroche, P. (2005). A meta-analytical investigation of the relationship between corporate social and financial performance, Revue de Gestion des Resources Humaines, 57, pp. 18-41.

Aoki, M. (1990). Toward an economic model of the Japanese firm, Journal of Economic Literature, 28(1), pp. 1-27.

Aupperle, K. E., Carroll, A. B. and Hatfield, J. D. (1985). An empirical examination of the relationship between corporate social responsibility and profitability, Academy of Management Journal, 28(2), pp. 46-463.

\footnotetext{
${ }^{5}$ Long-term orientation is relevant to "the fostering of virtues oriented toward future rewards - in particular, perseverance and thrift." Alternatively, shortterm orientation refers to "the fostering of virtues related to the past and present - in particular, respect for tradition, perseverance of "face," and fulfilling social obligations" [Hofstede et al., 2010, p. 239]. Indulgence refers to "a tendency to allow relatively free gratification of basic and natural human desires related to enjoying life and having fun." In contrast, restraint refers to "a conviction that such gratification needs to be curbed and regulated by strict social norms" [Hofstede et al., 2010, p. 281].
} 
Axel, M. (1995). Culture-bound aspects of Japanese management, Management International Review, 35(2), pp. 57-73.

Axinn, C., Blair, M., Heorhiadi, A. and Thach, S. (2004). Comparing ethical ideologies across cultures, Journal of Business Ethics, 54(1), 103-119.

Backman, J. (1975). Social Responsibility and Accountability. (New York University Press, New York, NY).

Basu, D. R. and Miroshnik, V. (2003). National culture, organizational culture and corporate performances of Japanese multinational companies: A structural equation modelling approach, Keiei-to-Keiei, 83(3), pp. 20-231.

Baydoun, N. and Willett, R. (1995). Cultural relevance of Western accounting systems to developing countries, Abacus, 31(1), pp. 67-92.

Bebbington, J. and Dillard, J. (2009) Social Sustainability: An OrganizationalLevel Analysis. Dillard, J., Dujon, V. and King, M., "Understanding the Social Dimension of Sustainability," (Routledge, New York) pp. 157-173.

Blodgett, J. G., Lu, L.-C., Rose, G. M. and Vitell, S. J. (2001). Ethical sensitivity to stakeholder interests: A cross-cultural comparison, Journal of the Academy of Marketing Science, 29(2), pp. 190-202.

Broomhill, R. (2007). Corporate social responsibility: Key issues and debates. Dunstan Paper. Retrieved from http://www.dunstan.org.au/resources/publ ications/Dunstan_Papers_No_1_2007.pdf.

Brown, S. C., Mason, C. A., Lombard, J. L., Martinez, F., Plater-Zyberk, E., Spokane, A. R., Newman, F. L., Pantin, H. and Szapocznik, J. (2009). The relationship of built environment to perceived social support and psychological distress in Hispanic elders: The role of "eye on the street", Journal of Gerontology: Social Sciences, 64(2), pp. 234-246.

Brown, B. and Perry, S. (1994). Removing the financial performance halo from Fortune's 'most admired' companies, Academy of Management Journal, 37(5), pp. 1347-1359.

Buck, T. and Shahrim, A. (2005). The translation of corporate governance changes across national cultures: The case of Germany, Journal of International Business Studies, 36(1), pp. 42-61.

Buhr, H. and Grafström, M. (2004). Corporate social responsibility, edited in the business press. Paper presented at the conference on Corporate Social Responsibility in the Era of Transforming Welfare State, Florence, Italy.

Campbell, J. L. (2007). Why would corporate behave in socially responsible ways? An institutional theory of corporate social responsibility, Academy of Management Review, 32(3), pp. 946-967.

Carroll, A. B. (1999). Corporate social responsibility: Evolution of a definitional construct, Business and Society, 38(3), pp. 268-295.

Chang, J. and Ding, C. G. (1995). The influence of culture on industrial buying selection criteria in Taiwan and Mainland China, Industrial Marketing Management, 24(4), pp. 277-284.

Chih, H.-L., Chih, H.-H. and Chen, T.-Y. (2010). On the determinants of corporate social responsibility: International evidence on the financial industry, Journal of Business Ethics, 93(1), pp. 115-135. 
Cochran, P. L. and Wood, R. A. (1984). Corporate social responsibility and financial performance, Academy of Management Journal, 27(1), pp. 42-56.

Cohen, J. R., Pant, L. W. and Sharp, D. J. (1996). A methodological note on crosscultural accounting ethics research, International Journal of Accounting, 31(1), pp. 55-66.

Cruz, L. B. and Boehe, D. M. (2010). How do leading retail MNCs leverage CSR globally? Insights from Brazil, Journal of Business Ethics, 91(2), pp. 243-263.

Davidson K. (2009). Ethical concerns at the bottom of the pyramid: Where CSR meets BOP, Journal of International Business Ethics, 2(1), pp. 22-32.

Decker, O. S. (2004). Corporate social responsibility and structure change in financial services, Managerial Auditing Journal, 19(6), pp. 712-728.

Donleavy, G. D., Lam, K.-C. J. and Ho, S. S. M. (2008). Does East meet West in business ethics: An introduction to the special issue, Journal of Business Ethics, 79(1-2), pp. 1-8.

Eilbert, H. and Parket, I. R. (1973). The current status of corporate social responsibility, Business Horizons, 16(4), pp. 5-14.

Elkington, J. (2006). Governance for sustainability, Corporate Governance: An International Review, 14(6), pp. 522-529.

Friedman, M. (1970). The social responsibility of business is to increase profits, New York Times Magazine, September 13, pp. 32-33, 122, 124, 126.

Fryxell, G. E. and Jia, W. (1994). The Fortune corporate "reputation" index: Reputation for what? Journal of Management, 20(1), pp. 1-14.

Graafland, J., Eijffinger, S. C. W. and Smid, H. (2004). Benchmarking of corporate social responsibility: Methodological problems and robustness, Journal of Business Ethics, 53(1-2), pp. 137-152.

Graafland, J., Eijffinger, S. C. W., Stoffele, N. C. G. M., Smid, H. and Coldeweijer, A. M. (2003). Corporate social responsibility of Dutch companies: Benchmarking and transparency. Retrieved from http://www.tilburguniver sity.edu/upload/627cea31-fc57-4fa5-8070-9ea01222213359_publicatie.pdf.

Gray, S. J. (1988). Towards a theory of cultural influence on the development of accounting systems internationally, Abacus, 24(1), pp. 1-15.

Gray, S. J. and Verma, S. (1998). The impact of culture and politics on accounting development and change: An exploratory framework and application to India, Indian Accounting Review, 2(1), pp. 1-7.

Griffin, J. J. and Mahon, J. F. (1997). The corporate social performance and corporate financial performance debate: Twenty-five years of incomparable research, Business and Society, 36(1), pp. 5-31.

Grosser, K. and Moon, J. (2005). Gender mainstreaming and CSR: Reporting workplace issues, Journal of Business Ethics, 62(4), pp. 327-340.

Habisch, A., Jonker, J., Wegner, M. and Schmidpeter, R. (2005) Corporate Social Responsibility across Europe. (Springer, Berlin).

Hancock, J. (2005). Investing in Corporate Social Responsibility: A Guide to Best Practice, Business Planning $\&$ the UK's Leading Companies. (Kogan Page London). 
Ho, F. N., Wang, H.-M. D. and Vitell, S. J. (2012). A global analysis of corporate social performance: The effect of cultural and geographic environment, Journal of Business Ethics, 107(4), pp. 423-433.

Hofstede, G. (1980a). Cultur's Consequences: International Differences in WorkRelated Values. (Sage, Beverly Hills, CA).

Hofstede, G. (1980b). Motivation, leadership, and organization: Do American theories apply abroad? Organizational Dynamics, 9(1), pp. 42-62.

Hofstede, G. (1994). Management scientists are human, Management Science, 40(1), pp. 4-13.

Hofstede, G. (2001). Culture's Consequences: Comparing Values, Behaviors, Institutions and Organizations across Nations. (Sage, Thousand Oaks, $\mathrm{CA}$ ), co-published in the PRC as Vol. 10 in the Shanghai Foreign Language Education Press SFLEP Intercultural Communication Reference Series, 2008.

Hofstede, G., Hofstede, G. J. and Minkov, M. (2010). Cultures and Organizations: Software of the Mind, 3rd Ed. (McGraw-Hill, New York, NY).

Ilir, H. and Hans, V. (2010). Explaining the diversity in the worldwide diffusion of codes of good governance, Journal of International Business Studies, 41(4), pp. $710-726$.

Jaeger, A. M. (1986). Organization development and national culture: Where's the fit?, Academy of Management Review, 11(1), pp. 178-190.

Jensen, M. (2002). Value maximization, stakeholder theory, and the corporate objective function, Business Ethics Quarterly, 12(2), pp. 235-256.

Levitt, T. (1958). The dangers of social responsibility, Harvard Business Review, 36(5), pp. 41-50.

Licht, A. N., Goldschmidt, C. and Schwartz, S. H. (2005). Culture, law, and corporate governance, International Review of Law and Economics, 25(2), pp. 229-255.

Maignan, I. (2001). Consumer' perception of corporate social responsibilities: A cross cultural comparison, Journal of Business Ethics, 30(1), pp. 57-72

Maignan, I. and Ralston, D. A. (2002). Corporate social responsibility in Europe and the U.S.: Insights from businesse' self-presentations, Journal of International Business Studies, 33(3), pp. 497-514.

Margolis, J. D. and Walsh, J. P. (2003). Misery loves companies: Rethinking social initiatives by business, Administrative Science Quarterly, 48(2), pp. 268-305.

McWilliams, A., Siegel, D. S. and Wright, P. M. (2006) Guest editor' introduction corporate social responsibility: Strategic implications, Journal of Management Studies, 43(1), pp. 1-18.

Moneva, J. M., Archel, P. and Correa, C. (2006). GRI and the camouflaging of corporate unsustainability, Accounting Forum, 30(2), pp. 121-137.

Moon, J. (2004). Government as a driver of CSR. Research Paper Series International Centre for Corporate Social Responsibility (ICCSR), Business School Nottingham University. Retrieved from http://195.130.87.21:8080/ dspace/bitstream/123456789/1102/1/20-Government\%20as\%20a\%20Driver \%20of\%20Corporate\%20Social\%20Responsibility\%20The\%20UK\%20in\%20 Comparative\%20Perspec.pdf. 
OECD (2000). Corporate governance in OECD member countries: Recent developments and trends. Retrieved from http://www.oecd.org/daf/corpo rate-affairs/governanc.

Once, S. and Almagtome, A. (2014). The relationship between Hofstede's national culture values and corporate environmental disclosure: An international perspective, Research Journal of Business \& Management, 1(3), pp. 279-304.

Orlitzy, M., Schmidt, F. L. and Rynes, S. L. (2003). Corporate social and financial performance: A meta-analysis, Organization Studies, 24(3), pp. 403-441.

Peiyuan, G. (2005). Corporate environmental reporting and disclosure in China. CSR Asia. Retrieved from http://www.csr-asia.com/upload/environmentalr eporting.pdf.

Peng, Y.-S., Dashdeleg, A.-U. and Chih, H. L. (2012). Does national culture influence firm's CSR engagement: A cross country study, International Proceedings of Economics Development $\&$ Research, 58(9), pp. 40-44.

Perera, M. H. B. (1989). Accounting in developing countries: A case for localized uniformity, British Accounting Review, 21(2), pp. 141-158.

Perrini, F., Pogutz, S. and Tencati, A. (2006). Developing Corporate Social Responsibility: A European Perspective. (Edward Elgar Publishing Cheltenham, Gloucestershire).

Pfeffer, J. (2010). Building sustainable organizations: The human factor, Academy of Management Perspective, 24(1), pp. 34-45.

Porter, M. E. and Kramer, M. R. (2002). The competitive advantage of corporate philanthropy, Harvard Business Review, 80(12), pp. 56-68.

Posnikoff, J. F. (1997). Disinvestment from South Africa: They did well by doing good, Contemporary Economic Policy, 15(1), pp. 76-86.

Prahalad, C. K. and Hammond, A. (2002). Serving the Worl's Poor, Profitably, Harvard Business Review, 80(9), pp. 48-58.

Radebaugh, L. H. and Gray, S. J. (2002) International Accounting and Multinational Enterprises, 5th Ed. (John Wiley \& Sons New York, NY).

Rallapalli, K., Vitell, S. J., Wiebe, F. A. and Barnes, J. H. (1994). Consumer ethical beliefs and personal traits: An exploratory analysis, Journal of Business Ethics, 13(7), pp. 487-495.

Ringov, D. and Zollo, M. (2007). Corporate responsibility from a socioinstitutional perspective: The impact of national culture on corporate social performance, Corporate Governance, 7(4), pp. 476-485.

Rosam, I. and Peddle, R. (2004) Implementing Effective Corporate Social Responsibility and Corporate Governance: A Guide. (British Standards Institution, London).

Rowley, T. and Berman, S. (2000). A brand new brand of corporate social performance, Business and Society, 39(4), pp. 397-418.

Scholtens, B. and Dam, L. (2007). Cultural values and international differences in business ethics, Journal of Business Ethics, 75(3), pp. 273-284.

Steensma, K., Marino, L. and Weaver, K. (2000). Attitudes toward cooperative strategies: A cross-cultural analysis of entrepreneurs, Journal of Personality of International Business Studies, 31(4), pp. 591-609. 
Svensson, G., Wood, G., Singh, J., Carasco, E. and Callaghan, M. (2009). Ethical structures and processes of corporations operating in Australia, Canada, and Sweden: A longitudinal and cross-cultural study, Journal of Business Ethics, 86(4), pp. 485-506.

Tan, J. and Chow, I. H.-S. (2009). Isolating cultural and national influence on value and ethics: A test of competing hypotheses, Journal of Business Ethics, $88(1)$, pp. 197-210.

Thanetsunthorn, N. (2014). Ethical organization: The effects of national culture on CSR, Organization Development Journal, 32(3), pp. 89-109.

Thanetsunthorn, N. (2015). The impact of national culture on corporate social responsibility: Evidence from cross-regional comparison, Asian Journal of Business Ethics, 4(1), pp. 35-56.

Thanetsunthorn, N. and Wuthisatian, R. (2016). Current state of corporate governance: Global business and cultural analysis, Management Research Review, 39(11), pp. 1431-1446.

Tice, D. M. and Baumeister, R. F. (2004). Masculinity inhibits helping in emergencies: Personality does predict the bystander effect, Journal of Personality and Social Psychology, 49(2), pp. 420-428.

Trompenaars, F. and Hampden-Turner, C. (1997) Riding the Waves of Culture: Understanding Cultural Diversity in Business. (McGraw Hill, New York, NY).

Visser, W. (2008) Corporate Social Responsibility in Developing Countries. Crane, A., McWilliams, A., Matten, D., Moon, J. and Siegel, D., "The Oxford Handbook of Corporate Social Responsibility," (Oxford University Press, Oxford) pp. 473-479.

Vitell, S. J. and Festervand, T. A. (1987). Business ethics: Conflicts, practices and beliefs of industrial executives, Journal of Business Ethics, 6(2), pp. 111-122.

Waddock, S. A. and Graves, S. B. (1997). The corporate social performance financial performance link, Strategic Management Journal, 18(4), pp. 303-319.

Walsh, J. P., Weber, K. and Margolis, J. D. (2003). Social issues and management: Our lost cause found, Journal of Management, 29(6), pp. 859-881.

Williams, G. and Zinkin, J. (2008). The effect of culture on consumers' willingness to punish irresponsible corporate behaviour: Applying Hofsted's typology to the punishment aspect of corporate social responsibility, Business Ethics: A European Review, 17(2), pp. 210-226.

World Bank (2001). Corporate governance: A framework for implementation. Retrieved from http://www.worldbank.org.

Wu, M.-L. (2006). Corporate social performance, corporate financial performance and firm size, Journal of Amrican Academy of Business, Cambridge, 8(1), pp. $163-171$.

Yoo, B. and Donthu, N. (2002). The effects of marketing education and individual cultural values on marketing ethics of students, Journal of Marketing Education, 24(2), pp. 92-103. 